\title{
ASSESSMENT OF SITE AND SOIL CHARACTERISTICS \\ OF RILL EROSION \\ FOLLOWING THE LOCKHEED FIRE \\ IN THE LITTLE CREEK WATERSHED, \\ SWANTON PACIFIC RANCH
}

\author{
A Thesis \\ presented to \\ the Faculty of California Polytechnic State University \\ San Luis Obispo
}




\begin{abstract}
In Partial Fulfillment
of the Requirements for the Degree

Masters of Science in Agriculture, with Specializations in Soil Science
\end{abstract}

by

Lynette K. Niebrugge

June 14, 2012 
(C) 2012

Lynette K. Niebrugge

ALL RIGHTS

RESERVED 


\section{COMMITTEE MEMBERSHIP}

TITLE:

AUTHOR:

DATE SUBMITTED:

COMMITTEE CHAIR:

COMMITTEE MEMBER:

COMMITTEE MEMBER:
Assessment of Site and Soil Characteristics of Rill Erosion Following the Lockheed Fire in the Little Creek Watershed, Swanton Pacific Ranch

Lynette K. Niebrugge

June 14, 2012

Lynn E. Moody, Ph.D.

Thomas J. Rice, Ph.D.

Brian C. Dietterick, Ph.D. 


\begin{abstract}
Assessment of Site and Soil Characteristics of Rill Erosion Following the Lockheed Fire in the Little Creek Watershed, Swanton Pacific Ranch
\end{abstract}

Lynette K. Niebrugge

The Lockheed Fire occurred in August 2009, burning 7,819 acres of the coastal mountains north of Santa Cruz, California. The fire burned a large portion of the Scotts Creek watershed, including over $90 \%$ of the Little Creek watershed, much of which is on Cal Poly's Swanton Pacific Ranch (SPR). After intense winter rains in 2010 there was a significant amount of hillslope-derived sediment deposited on the roads and in the creek. A large portion of this material was derived from two chaparral hillslopes. These hillslopes were identified as the only two hillslopes within the Little Creek subwatershed where an extensive network of rill erosion had occurred. The purpose of this study was to determine what factors were related to the erosion process on two burned hillslopes. Water repellency, infiltration, saturated hydraulic conductivity, and particle size class were assessed to determine how the impacts of the fire affect the soil physical properties where rill erosion occurred. In order to address this goal, the soil physical properties were characterized on two hillslopes influenced by three different types of parent material: Santa Cruz mudstone, Santa Margarita sandstone and colluvium derived mainly from the Santa Cruz mudstone. The study, consisted of 10 transects and three sampling points at 3, 18 and $27 \mathrm{~m}$, on $45-80 \%$ southeastern facing slopes. The vegetation consisted of knobcone pine chaparral mix, transitioning down slope to a chaparral mix. The results showed slope length, clay content and infiltration, were statistically significant. Hydraulic conductivity $\left(\mathrm{K}_{\text {sat }}\right)$ and slope steepness were not significant, but were included as associated variables with the occurrence of rilling. The study has provided information about post fire soil properties to determine what factors contribute to rill erosion causing the sedimentation into the streams. The observation from the study site can be used in similar conditions within the coastal mountain range setting, thus helping to create models for future planning of the overall watershed management.

Keywords: post fire effects on soil, soil physical properties, hydrologic function of soil, rill erosion 


\section{ACKNOWLEDGEMENTS}

I would like to thank my committee members: Dr. Lynn Moody for all her support and encouragement throughout this entire process, Dr. Brian Dietterick for giving me such a great opportunity to conduct my research and allowing me to live at Swanton Ranch, and Dr. Tom Rice for his great ideas and humor.

A special thanks to those who helped me throughout my research: Gerald Weber, for his extensive knowledge in geology and support in planning a field study, Jim West for his amazing Botany skills and storytelling abilities, Roberta Smith for her vast knowledge of the geology in Scotts Creek Watershed, Ron Taskey for his challenging and entertaining conversation, Michael Founds and Michael Murphy the two interns who helped make my field work possible, Drew Perkins and Drew Loganbill for all their knowledge within Little Creek, Russ White for all his assistance and ideas, and to the employees of Swanton Ranch for all their support.

I would also like to express my appreciation to my co-workers at the LTBMU, US Forest Service who gave me work experience, challenging opportunities, as well as encouragement to pursue my goals for a higher education in the field of soil science.

Last, and most importantly, thanks to my family especially my brother Darryn for proof reading every draft of my thesis and to my close friends, for all their support and encouragement.

Partial funding for this project was provided by a California State University Systemwide Agricultural Research Initiative grant. 


\section{TABLE OF CONTENTS}

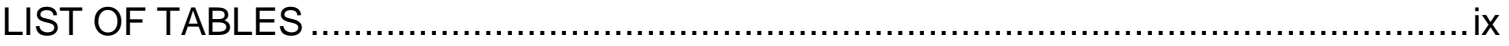

LIST OF FIGURES

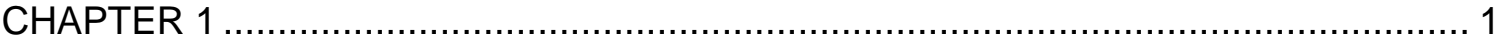

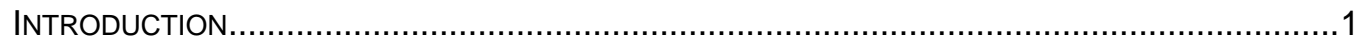

Background Information and Problem Statement ................................. 1

Statement of Subgoal to be Investigated............................................. 7

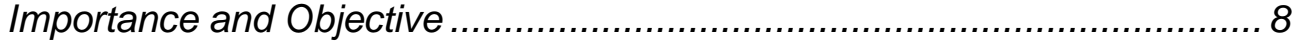

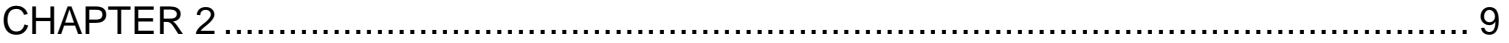

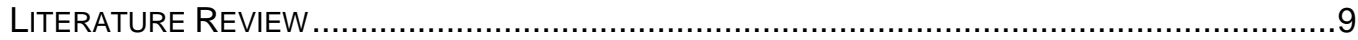

Soil Water Repellency............................................................... 10

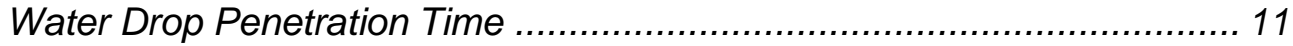

Hydrologic Factors ................................................................. 12

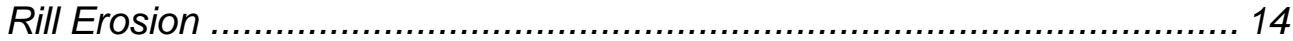

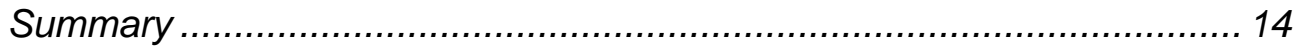

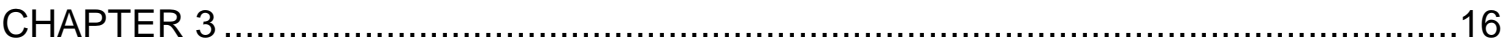

METHODS AND MATERIALS …………………………………………………16

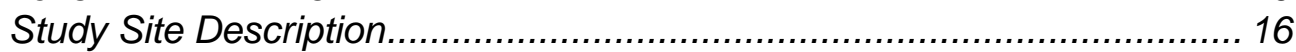

Field Methods .............................................................................. 21

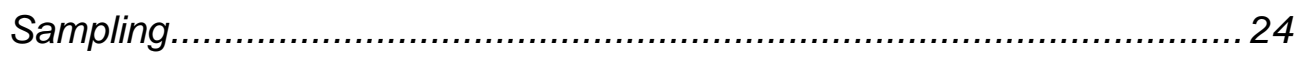

Characteristics measured in the field ............................................... 25

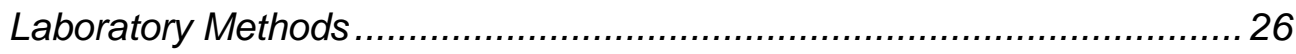

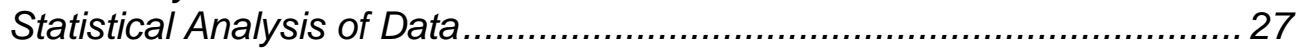

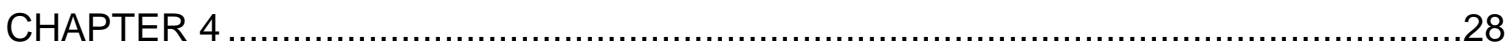

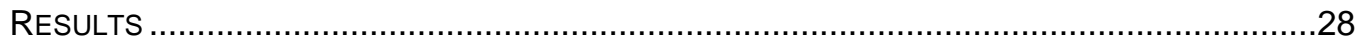

Landscape Characteristic............................................................. 28

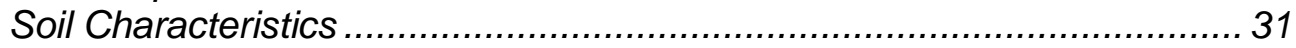

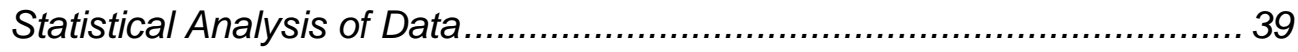

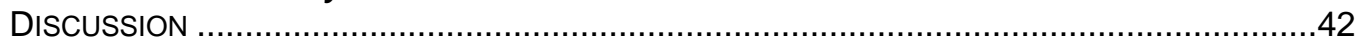

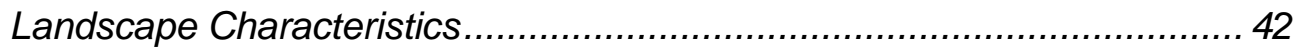

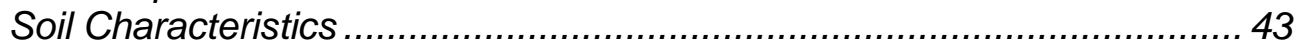

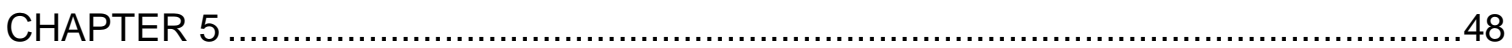

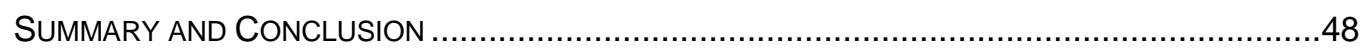

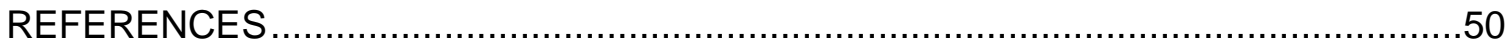

vii 


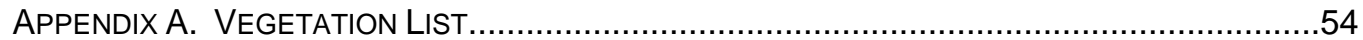

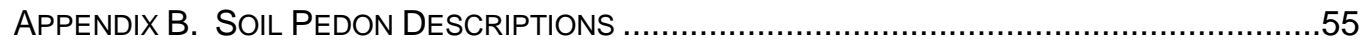

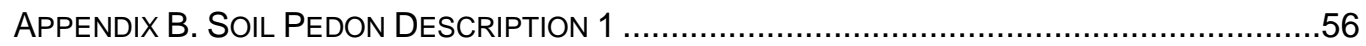

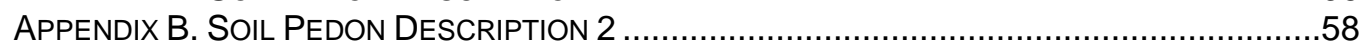

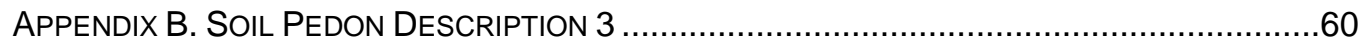

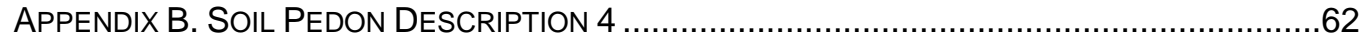

ApPendix C. Soll PEdon 1, Hillslope 1: Shoulder, TransectS 1-3 .........................64

APPENDIX D. HILLSLOPE 1: BACKSLOPE ASSESSMENT TRANSECTS 4-6 ......................65

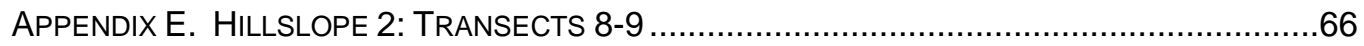

ApPendix F. HILlsLope 2: BACKSLOPE PEdON 3, TRANSECT 10-11 ............................67

APPENDIX G. StATISTICAL ANALYSIS, BINARY LOGISTICAL REGRESSION .........................68

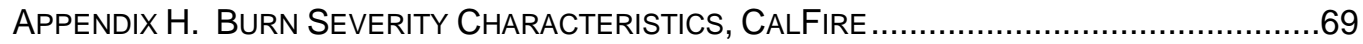




\section{LIST OF TABLES}

Table 1. Soil Series names and Family Classifications of soils mapped in the Little Watershed. Soil Survey Staff, Natural Resources Conservation Service, United States Department of Agriculture. Official Soil Series Descriptions. Source: Soil Survey of Santa Cruz County, California ............................................................. 20

Table 2. Landscape Characteristics of the two Hillslopes and transect lines with the presence and absence of rill erosion.

Table 3. Soil characteristics for non-rill and rill erosion transect sample sites.

Table 4. The mean with a standard deviation based on the sample value for Organic Matter, Carbon and Nitrogen percent and the Carbon/Nitrogen ratio of both hillslopes with and without the presence of rill erosion.

Table 5. Binary logistical regression analysis for predictors and the odds ratio of rill erosion occurrence.

Table 6. Plant Identification on research hillslopes post-fire. Plant ID by Botanist Jim West

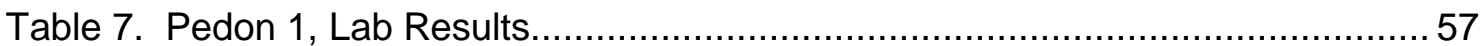

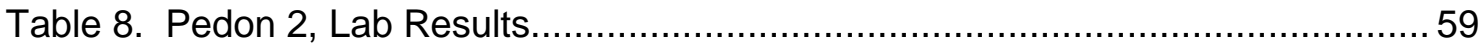

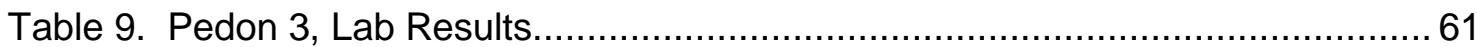

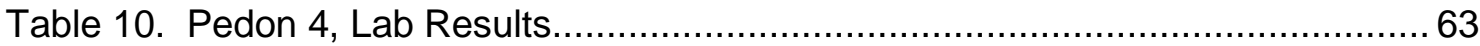




\section{LIST OF FIGURES}

Figure 1. Swanton Pacific Ranch boundary displaying the perennial and intermittent streams within Scotts Creek Watershed. Source:

http://www.spranch.org/about.Idml.

Figure 2. Burn Severity derived from US Forest Service Burn Area Reflectance Classification (BARC). This is a satellite-derived map comparing pre-fire and post-fire vegetation conditions. Source: http://www.spranch.org/about.Idml.

Figure 3. Hillslope 1: a) View displaying the network of rill erosion where transects T4-T6 were located. b) Close up illustrating the width and depth of the erosion. The photos were taken in March 2010 during the rill erosion study, approximately 7 months post-fire and 2 months past the January rain event.

Figure 4. Location of Little Creek subwatershed.

Source: NRES GIS Database, 2011

Figure 5. Geology Map of Little Creek Watershed.

Source: Geologic Map Data (Brabb, 1977)

Figure 6. Vegetation map units of Swanton Pacific Ranch.

Source: http://www.spranch.org/about.Idml 19

Figure 7. Series Map of Little Creek Watershed. Source: SSURGO.....

Figure 8. Photo of Hillslopes 1 and 2 at the time of sampling, nearly one year post-fire 07/2010.

Figure 9. Study Location, Two hillslopes above Little Creek. The black dots represent the transect beginning and end of Transect lines T1-T11.T7 was dismissed from the research; therefore the site location is not indicated on this map. The yellow dots indicate sample points ( $9 \mathrm{~m}, 18 \mathrm{~m}$ and $27 \mathrm{~m}$ ) along each $30 \mathrm{~m}$ transect line.

Figure 10. Hillslope 1, a) Non-rilled sites transects T1- T3, Summit and Shoulder slope. b) Rilled sites transects T4-T6, on backslope.

Figure 11. Hillslope 2, a) Shoulder slope no rill erosion, transect T9. b) Rilled sites located on the backslope photo taken between transect T10 and T11.

Figure 12. Mean soil water repellency at a depth of $1 \mathrm{~cm}$ and $3 \mathrm{~cm}$ at transect sample locations (30, 60 and 90ft). Higher values colored red indicate strong repellency (>40sec), Yellow indicates moderate repellency ranging from 10-40 sec, Lower blue values are designate weak repellency $(<10 \mathrm{sec})$.

Figure 13. Mean soil water infiltration $\mathrm{ml} / \mathrm{min}$ verses $1 \mathrm{~cm}$ and $3 \mathrm{~cm}$ depth for transect site locations; a) Non-rilled T1,T2 and T3, b) Rilled T4,T5 and T6,

c) Non-rilled T8 and T9, d) Rilled T10 and T11. Light blue indicates $1 \mathrm{~cm}$ infiltration; 
dark blue indicates $3 \mathrm{~cm}$ infiltration rates with error bars representing variability in the measurements at a standard deviation.

Figure 14. $\log 10$ Saturated Hydraulic Conductivity $\left(\mathrm{K}_{\mathrm{sat}}\right) \mathrm{cm} / \mathrm{hr}$ mean values are presented with error bars as \pm 1 SD (1 standard deviation). Non rilled transects represented by blue bars and rilled are represented by green bars.

Figure 15. Error of Probability of Rill Erosion of statistically significant variables:

a) clay percent, b) infiltration and c) slope length

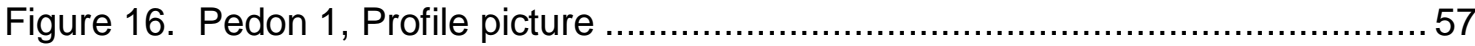

Figure 17. Pedon 2, Profile picture ............................................................. 59

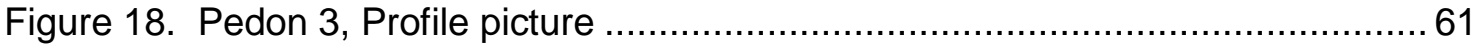

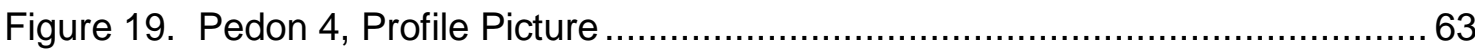

Figure 20. a)Taken looking east toward the beginning of transect 2. b) Photo taken at the start of transect 3, looking west towards the end of the transect.

Figure 21. a) Taken from the bottom of the assessment site near transect 6 looking up toward transects 4 and 5 . This photo also displays the amount of vegetation that has grown back one year post-fire.

Figure 22. Hillslope 2, a) Photo of Shoulder backslope transect T8, b) Photo of transect T9

Figure 23. Hillslope 2, a) Photo of transect 10 and Pedon 3, b) Photo looking up slope from T11 


\section{CHAPTER 1}

Introduction

\section{Background Information and Problem Statement}

Scotts Creek Watershed has a history of mass wasting and surficial erosion as a result of climate, geology, soils, steep slopes and high relief. By means of land alterations over the years, natural and anthropogenic sedimentation has been accelerated (SCWC, unpublished data, 2000). One type of land alteration is wildfires, which are a common occurrence throughout California. These have a large effect on watershed characteristics and functions creating a major concern.

Scotts Creek Watershed is located in the Santa Cruz Mountains, approximately 7,689 ha in size, and discharges into the Pacific Ocean in the Monterey Bay National Marine Sanctuary. Scotts Creek consists of several subwatersheds. From down-to upstream (south to north) from the estuary the subwatersheds are: Queseria Creek (193 ha), Archibald Creek (170 ha), Winter Creek (60 ha), Little Creek (528 ha), Big Creek (2893 ha), Mill Creek (971 ha), Upper Scotts Creek (2,107 ha), and Lower Scotts Creek (608 ha) (Figure 1) (NRES Dept. GIS Database, 2011). All of these subwatersheds are perennial streams, except Archibald Creek, Queseria Creek and Winters Creek, which are intermittent streams (SCWC, unpublished, 2000). Little Creek is located in the Santa Cruz Mountains and recently experienced the Lockheed Fire in August 2009. The last fire recorded before this was in 1948 (SCWC, unpublished data, 2000). 


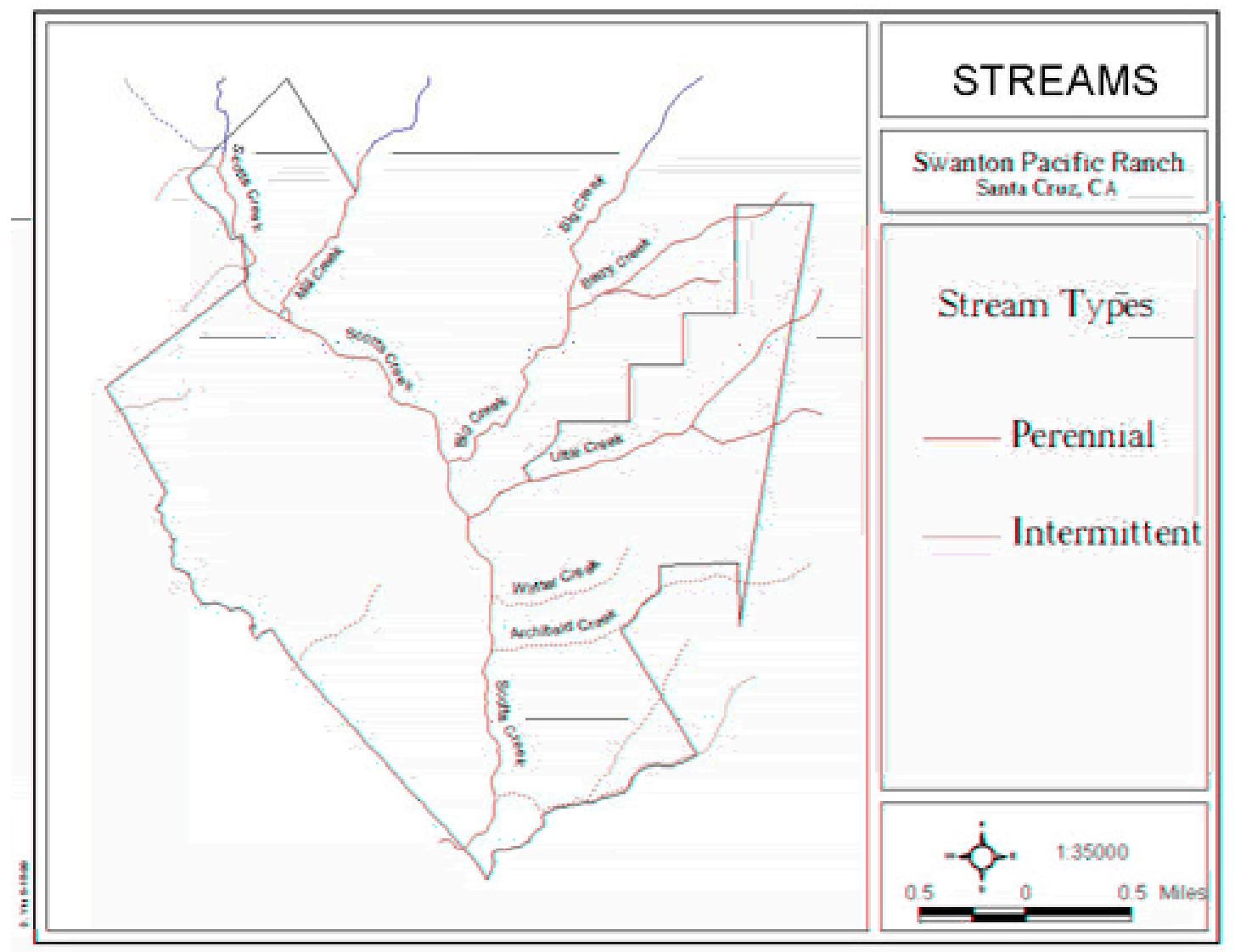

Figure 1. Swanton Pacific Ranch boundary displaying the perennial and intermittent streams within Scotts Creek Watershed. Source: http://www.spranch.org/about.Idml

In August 2009, the Lockheed Fire burned a total of 3164 ha (7,819 acres) of the coastal mountains north of Santa Cruz, California. Approximately 486 ha of the Little Creek watershed, which is partially within Cal Poly's Swanton Pacific Ranch, was burned by the fire. The Lockheed Fire Assessment report categorized Little Creek Watershed as the second highest priority watershed affected by the fire, burning nearly 92\% of the watershed. A Burn Area Reflectance Classification (BARC) map (Figure 2), generated by satellite imagery of post-fire vegetation conditions and ground 
observations, concluded the burn severity by land area within the burn was: $11.2 \%$ very high, 30.9\% high, 52.7\% moderate and 5.3\% low (Cal Fire, 2009). The combination of topography, weather and different vegetation types throughout the watershed contributed to the fire conditions. These conditions created an uneven pattern of unburned and burned areas, which ranged from low to very high burn severities (Figure 2). Due to the loss of vegetation and potential for alteration of soil properties by the fire, the major concern was how hydrologic processes of the watershed would respond post-fire with the seasonal rains ahead. 


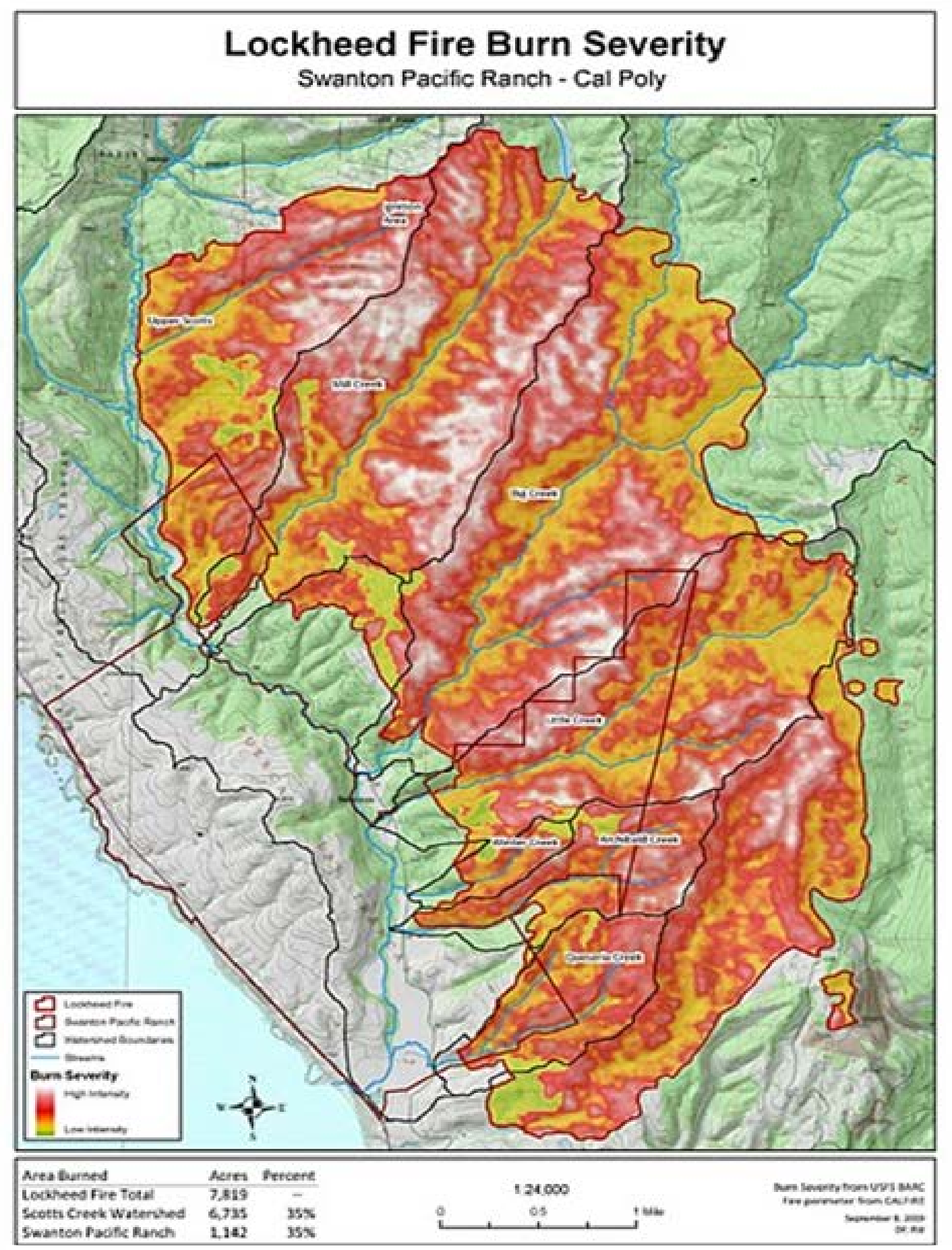

Figure 2. Burn Severity derived from US Forest Service Burn Area Reflectance Classification (BARC). This is a satellite-derived map comparing pre-fire and post-fire vegetation conditions. Source: http://www.spranch.org/about.Idml 
The lower portion of Little Creek watershed on Cal Poly Corporation property is managed by the College of Agriculture, Food, and Environmental Sciences (CAFES) and has provided numerous educational and commercial opportunities in forestry, range, and watershed management since 1993. A long-term water quality monitoring project has been in place for the past eight years and has proven to be particularly valuable, as it has provided researchers with substantial pre-fire data. The Lockheed Fire also provided opportunities for researching hydrological functions of the watershed post-fire. Students began to collect data immediately following the fire in order to aid in the determination of risks level posed by debris flows and the erosion processes which transpired from the steep and unstable slopes in post fire conditions.

Continuous water quality monitoring was conducted during each major rainfall event following the fire. Parameters included stream flow, suspended sediment concentration, turbidity and rainfall amount. Visual monitoring on hillslopes was also conducted. The first post fire storm occurred on October 13, 2009 which had a peak maximum rainfall intensity of $1.33 \mathrm{in} / \mathrm{hr}$ for a10 minute duration. The peak flow for this storm was 11.07 CFC and, the turbidity at peak flow was 467 NTU with a suspended sediment concentration of $1837.2530 \mathrm{SSC}(\mathrm{mg} / \mathrm{l})$. After this event, the field evaluation identified isolated occurrences of channelized debris flows and dry ravel; however, no rill erosion transpired from this storm. The first storm to have a measurable impact on the water quality in Little Creek occurred five storms later on January 18, 2010. This storm had a maximum 10-minute rainfall intensity of $3.34 \mathrm{in} / \mathrm{hr}$, a much higher intensity than the past storm (SPR, 2010, unpublished data). The higher rainfall intensity in January resulted in higher turbidity levels of 2530 NTU and suspended sediment 
concentrations of $5012.3 \mathrm{SSC}(\mathrm{mg} / \mathrm{L})$ at the peak flow of the storm with at $12.49 \mathrm{CFS}$.

The increased turbidity and suspended sediment concentration in Little Creek prompted further observations throughout the watershed towards locating the origin of sediment loss from the steep slopes. An extensive network of rill erosion was identified on two hillslopes located in the North Fork of Little Creek subwatershed and minor rill erosion occurred in the upper portions of the watershed (Figure 3). The minor rills were found mainly in convergent slopes and did not have the width and depth compared to the network of rilling which transpired on the two hillslopes above the North Fork. Throughout subsequent storms in January and February the two hillslopes were visually monitored along with each rainfall event. The January event experienced the highest rainfall intensities for the season, significantly greater than all other events. Due to the extensive rill network and the increases in turbidity and suspended sediments concentrations in Little Creek, a study was conducted to quantify the amount of sediment attributable to rill erosion. The hillslope erosion study concluded that the total estimated sediment eroded was $99 \mathrm{~m}^{3} /$ acre (164 tons/acre) on a three acre hillslope area (Figure 3) (Marselek, unpublished data, 2010). Because of the extensive network of rill erosion and the amount of sediment loss calculated from the "Rill Erosion Study," further investigation was essential to determine what was causing rill erosion to occur. 

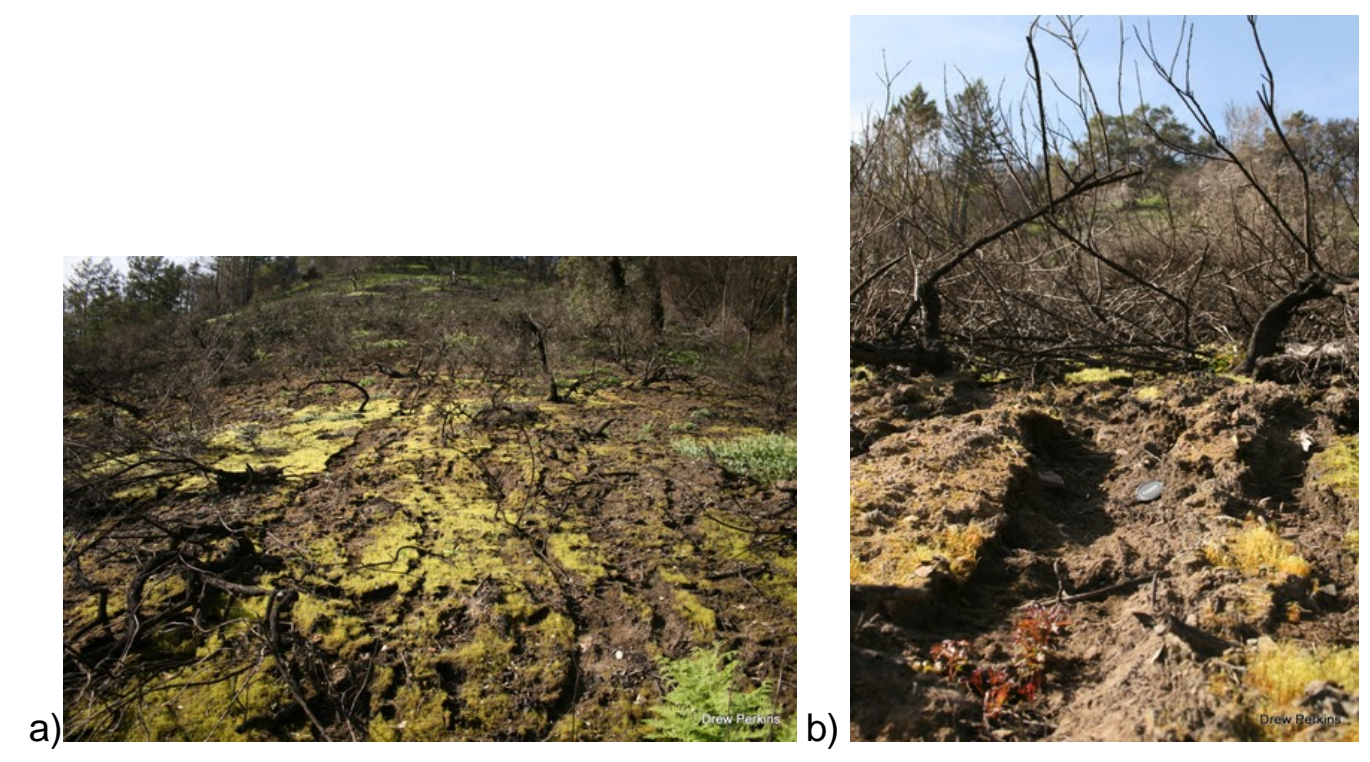

Figure 3. Hillslope 1: a) View displaying the network of rill erosion where transects T4T6 were located. b) Close up illustrating the width and depth of the erosion. The photos were taken in March 2010 during the rill erosion study, approximately 7 months post-fire and 2 months past the January rain event.

Overall Goal of the Project

The overall goal of this research project was to assess site characteristics and the soil properties to determine what factors contribute to the network of rill erosion that transpired from two burned hillslopes.

Statement of Subgoal to be Investigated

In order to address the overall goal, the project focused on collecting both observed and measured data for characteristics associated with hillslope non-rill and rill erosion. 
Importance and Objective

The influences of wildfire on watersheds are of major concern because fire alters the physical and biological characteristics and functions of a watershed. The Scotts Creek Watershed is particularly important because Scotts Creek is listed as critical habitat for anadromous fish, with federally endangered Coho salmon (Oncorhynchus kitsch) and federally threatened steelhead trout (Oncorhynchus

mykiss). Because Scotts Creek historically has contained the largest population for all three-year classes of Coho salmon, it has been classified as the most important creek in the Santa Cruz diversity stratum (National Marine Fisheries Service, 2010). Knowing that this watershed has a history of mass wasting and surficial erosion, it is important to determine if changes in hydrologic function have occurred in response to post-fire rain events (SCWC, unpublished data, 2000). Post-fire erosion causing increased sedimentation into these streams may enhance the threat to the critical habitat of the Coho and steelhead.

The study will provide post-fire soil properties to help determine what factors contribute to rill erosion causing the sedimentation into the streams. The post-fire observation for the study site can also be used in similar conditions within the coastal mountain range setting, thus helping to create models for future management of the overall watershed for critical habitat management. The objective of this study was to evaluate what factors contributed to the network of rill erosion on the two hillslope postfire. 


\section{CHAPTER 2}

\section{Literature Review}

California chaparral shrublands cover approximately 8.5 percent of the State's landscape (California Academy of Sciences. 2008). These chaparral communities are related to Mediterranean type climate and are prone to intermittent wildfires due to the dry hot season (Lloret and Zedler, 2009). The vegetation is predominately drought tolerant, and has adapted by leaf drop and the development of waxy leaf surfaces to retain moisture and prevent water loss through transpiration, thus creating a high resin content of the organic material (DeBano, 1981; Hubbert et al., 2006). The resin produced by the shrubland vegetation has over time created a natural water repellent soil. This natural soil water repellent layer is then enhanced when a wildfire transpires.

When a wildfire occurs and the vegetation is consumed, the fire creates a mosaic pattern of low, moderate, and high burn severities. The severity assumes the mosaic pattern based on the combination of the climate, winds, topography, distribution of vegetation, soil texture and soil moisture at the time of the fire (Huffman et al., 2001).

The consumption of above ground and below ground organic matter with varying degrees of heat and duration of time, create high to low soil burn severity, in turn inducing water repellency in the upper layers of the soil surface. An increase in soil water repellency reduces infiltration and negatively affects the hydrological conditions of the soil (DeBano, 2000). With the reduction in soil infiltration, the potential for surface erosion increases when high intensity rainfalls occurs and directly impacts the exposed, unvegetated soil surfaces of the hillslopes. 


\section{Soil Water Repellency}

Soil water repellency, also known as hydrophobicity, occurs when soil particles are resistant to wetting. Water repellency can be found in a wide range of vegetation types and climates (Doerr et al., 2000). When a water droplet comes in contact with the water repellent soil it will "bead up" forming a spherical shape and it is unable to be absorbed by the soil (Neary et al., 2005). The water repellent layer is normally covered by a severely burned soil or an ash layer (DeBano, 2000). The water repellent layer can vary in thickness, depth, and continuity on the soil surface, as well as below the soil surface, up to $5 \mathrm{~cm}$ depth.

Water repellent soils are common in both unburned and burned plant communities because of oils formed from the vegetation and decomposing organic matter coating soil particle surfaces. In burned conditions the repellency is induced by the heat of the fire which vaporizes hydrophobic and aliphatic hydrocarbons from the litter and soil organic matter (Huffman et al., 2001). When soil is heated, these compounds are vaporized and released into the atmosphere or forced deeper into the soil profile. Then the compounds condense on cooler soil particles at the surface or below the soil mineral surface. At the cooler depths, the soil particles become coated by the compounds. This creates a waxy surface that chemically bonds to the soil particles, resulting in a water repellent layer, which inhibits infiltration (DeBano, 2000). At a temperature of $175^{\circ} \mathrm{C}$ there is little to no development of repellency, at 175 $280^{\circ} \mathrm{C}$ repellency intensifies, and at temperatures above $280^{\circ} \mathrm{C}$ repellency is destroyed (DeBano,1981). Temperature is not the only factor that affects the degree of water repellency; the duration of heating develops repellency. The longer the heat 
source is present, the more the heat will penetrate deeper into the soil creating variability in water repellency (DeBano, 1981).

\section{Water Drop Penetration Time}

Two common methods of measuring water repellency post fire are the water drop penetration time (WDPT) and the Decagan Mini Disk Infiltrometer (MDI). The WDPT is the most common method used. This is the amount of time it takes a water droplet to adsorb into the soil. WDPT is determined when the droplet has changed from a convex shape to flat on the soil surface, and infiltration has occurred (Hubbert et al., 2006). Approximately 10 to 20 droplets are applied to the soil mineral surface at depths ranging from 0 to10 $\mathrm{cm}$. Once infiltration has occurred, the WDPT is recorded, the measurements for each depth are averaged and then water repellency is classified based on a common repellency index. The common repellency index is a standard classification used by researchers, which indicates the class intervals in seconds associated with the repellency persistency rating (Doerr et al., 2006). The modified water repellency index used; 0 - 1 second = non repellent, 1 -5 seconds = very low repellency, 5 -30 seconds = low repellency, $30-180$ seconds = moderate repellency, and $>180$ seconds $=$ extreme repellency (Hubbert et al., 2006).

The analyses of soil water repellency are normally tested at the surface and to depths from 1 to $5 \mathrm{~cm}$. Because of varying depths of the organic material, temperature of fire heating the soil and the length of time the fire persists on the ground; generally water repellency strength will increase as the depth increases. In California chaparral vegetation, it was observed that the amount of organic material spacing of vegetation 
played a role in the water repellency variation and depth of the wetted layer occurring in the soil (Hubbert et al., 2006). WDPT was measured at the surface, $2 \mathrm{~cm}$ and $4 \mathrm{~cm}$ depths; the results illustrated an increase in water repellent at lower subsurface depths of $4 \mathrm{~cm}$ from pre-fire to post-fire conditions. A greater variability in the distribution of water repellency was displayed at the surface than at 2 and $4 \mathrm{~cm}$ depths pre-fire. An increase in repellency was shown at the $2 \mathrm{~cm}$ and $4 \mathrm{~cm}$ post-fire sampling, 7 days and 76 days. The surface returned to its natural state of repellency after 76 days.

Samples were also taken both underneath shrub canopies and interspaced between the shrubs (Hubbert et al., 2006). Comparing pre-fire to post-fire conditions, moderate repellency pre-fire increased to extreme repellency post-fire under the shrub canopies, whereas the moderate repellency was found to be interspaced between shrub canopies post-fire. As a result of the difference in the degree of water repellency the soil water infiltration rates were also affected. Varying strengths of water repellency in the soil can inhibit the rate at which water moves through the soil.

\section{Hydrologic Factors}

Infiltration is the movement of water into the soil surface. Infiltration can be broken into two different scales of response time for water movement; short or longtime response. Sorptivity is considered a short-time response in infiltration. It is controlled by the soil moisture retention and the capability of soil to attract water through the capillary potential gradient. The long time response is hydraulic conductivity and reflects the gravity potential. Hydraulic conductivity is the rate of water flow through soil. The saturated hydraulic conductivity is the water movement 
through saturated soil and it is the ability of water to move through pore spaces when they are full of water. Both hydrologic factors can be measured by an infiltration rainfall simulator or a minidisk infiltrometer can be used to determine the short and long time response times of infiltration.

Water repellent layers restrict infiltration storage capacity, which is an area where water is retained, thus restricting the flow of water through the soil. As a result there is a decrease in the total amount of water infiltration, which alters the hydrologic cycle (Debano, 2000). Infiltration determines the proportion of water that moves by overland flow and when high intensity rainfall exceeds the infiltration capacity after a fire, surface runoff increases. This can change surface and subsurface flows which then affect streamflow. A study of rainfall and concentrated flow simulations were applied to unburned and burned areas of a sagebrush community to determine the surface soil infiltration and fire induced impacts on runoff and erosion. The infiltration rates in the year immediately following the fire were minimal, while year one and two infiltration rates were high. Decreasing infiltration rates on 30 to 40 percent slopes resulted in runoff occurring in 2 to 5 minutes and peak flow within the first 5 to 15 min of the rainfall simulations (Moody and Martin, 2001).

A steep sagebrush study, suggested infiltration variability was dependent upon vegetation and the degree of burn severity. In the burn sites, underneath shrubs, there was a 38 percent average reduction in infiltration located in the high severity zone. Interspaced between vegetation, infiltration was reduced by 45 percent. At these sites, rainfall exceeded the initial infiltration and storage capacity, thus initiating runoff resulting in a high occurrence of rill erosion (Pierson et al., 2008a). 


\section{Rill Erosion}

Soil erosion increases after wildfires and has been attributed to the degradation of soil aggregates, loss of vegetation, reduced infiltration and the increase in overland flow (Scott et al., 2009). Erosion is defined as the process of detachment and transportation of particles by means of wind of water. The most common recurring driving force of erosion following a wildfire are rainfall and overland flow (Scott et al., 2009). The level of erosion after a wildfire will be dependent upon the ground cover, where the fire has consumed the vegetation and the bare soils are exposed and unprotected from the energy of the raindrops, therefore more energy will be transmitted to the soil surface (Scott et al., 2009). After intense rain events an area may be subject to increased erosion and sedimentation.

A rill is formed when concentrated flows of water arrange into linear microchannels formed by overland flow depressions or breaks in slopes. Rills obtain their depth and width from increased water flow and erosive powers as water travels downslope. Recent studies of post fire erosion have attributed 80 percent of sediment loss to hillslope rill erosion (Moody and Martin, 2001). The volume of sediment that can be lost can range from 2 to 20 ton ha' . $^{-1}$

Summary

California chaparral ecosystems are prone to seasonal fire. The naturally occurring water repellent layer created by the vegetation may be enhanced by fire. The persistence and depth of the water repellent layer is dependent upon the vegetation spacing and burn severity. Due to the degree of water repellency the soil 
water infiltration rates will vary upon vegetation spacing and pre- and post-fire conditions. A decline in infiltration and soil water storage capacity can result in increased overland flow and erosion. Post-fire erosion can result high loss of sediments. 


\section{CHAPTER 3}

Methods and Materials

Study Site Description

\section{Location}

The study was conducted in the Little Creek watershed on Swanton Pacific Ranch (SPR), managed by CAFES and owned by the Cal Poly Corporation, San Luis Obispo. Swanton Pacific is situated on the northern coast of Santa Cruz County, CA approximately $22 \mathrm{~km}$ north of Santa Cruz, Ca (Figure 4). The Swanton Pacific Ranch encompasses 1294 ha of the Scotts Creek watershed. The elevation of the Scotts Creek watershed ranges from sea level to approximately $380 \mathrm{~m}$. Slopes are gradual to very steep, ranging from 0 to 90 percent slopes. 


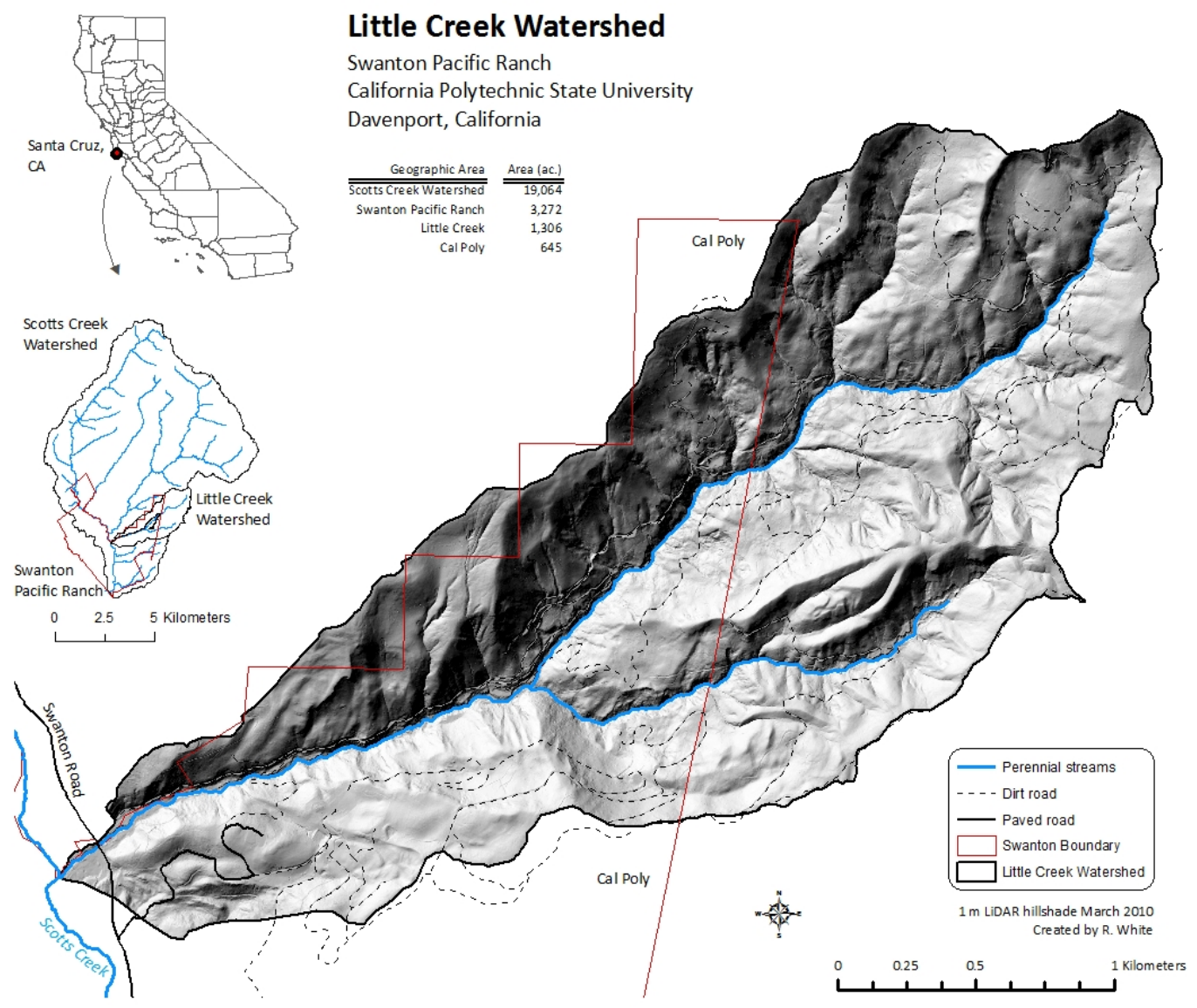

Figure 4. Location of Little Creek subwatershed. Source: NRES GIS Database, 2011

\section{Geology}

The Little Creek Watershed is part of the Coast Ranges geomorphic province. The watershed is on the Salinian structural block and is composed of several bedrock types, specifically granitic and metamorphic basement rock. The rock is overlain by layers of marine sedimentary rocks, in turn overlain by Quaternary colluvial and alluvial deposits. The bedrock geology found throughout the watershed is comprised of Paleozoic to Mesozoic quartz diorite and schist, Tertiary Santa Cruz Mudstone, and 
Tertiary Santa Margarita Sandstone (Brabb, 1997).

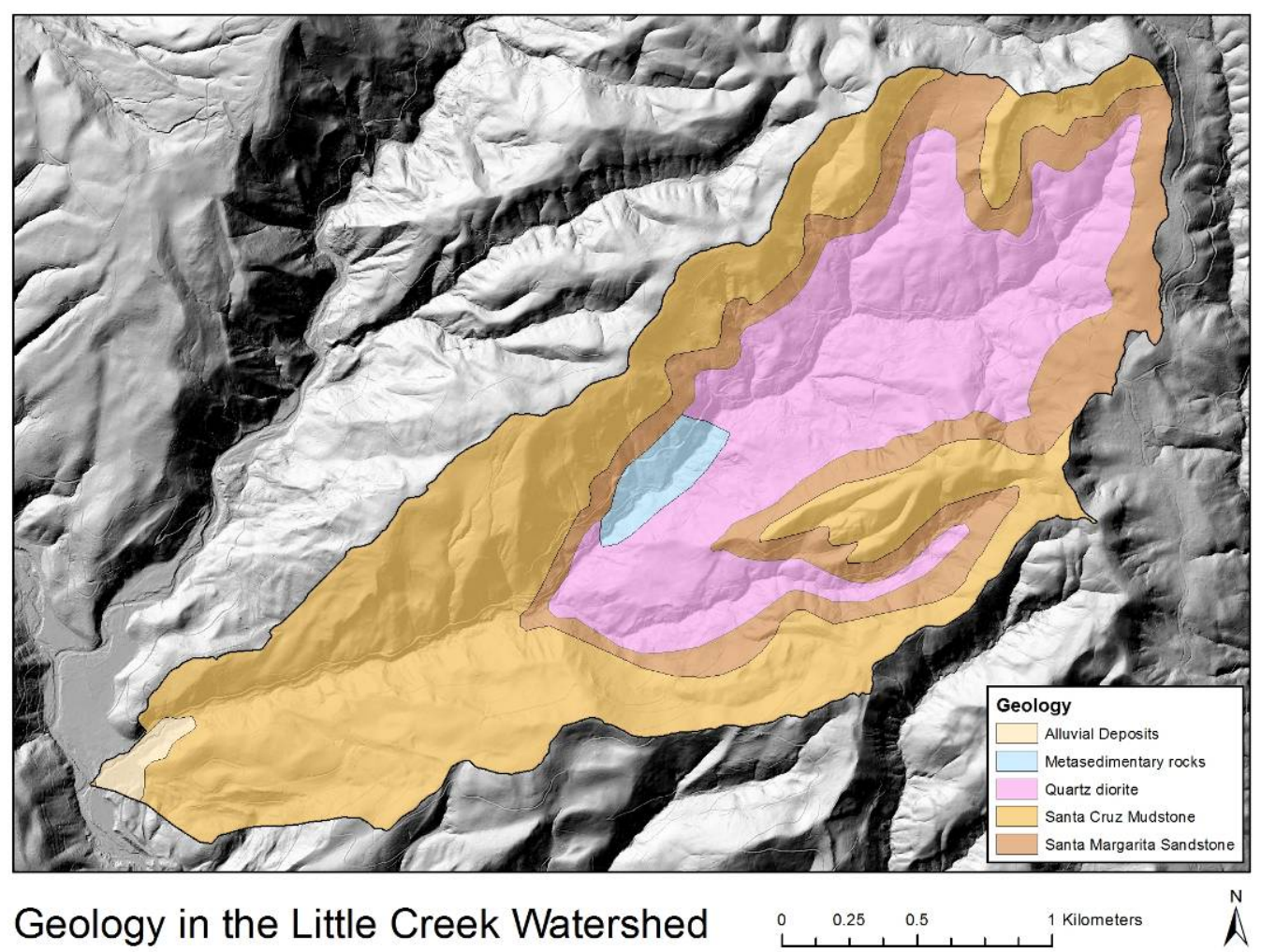

Figure 5. Geology Map of Little Creek Watershed. Source: Geologic Map Data (Brabb, 1977)

\section{Climate}

The region has a Mediterranean type climate with a coastal influence characterized by wet, cool winters, and cool, foggy, and dry summers. Swanton Pacific Ranch has a mean annual precipitation of $122 \mathrm{~cm}$. Most of the precipitation falls between November and April, based on a 30 year rainfall average (PRISM Climate Group, 2011). 


\section{Vegetation}

The watershed includes redwood forest, mixed conifer forest, chaparral, coastal scrub oak and grassland ecosystems (Bowman and Estrada, 1980).

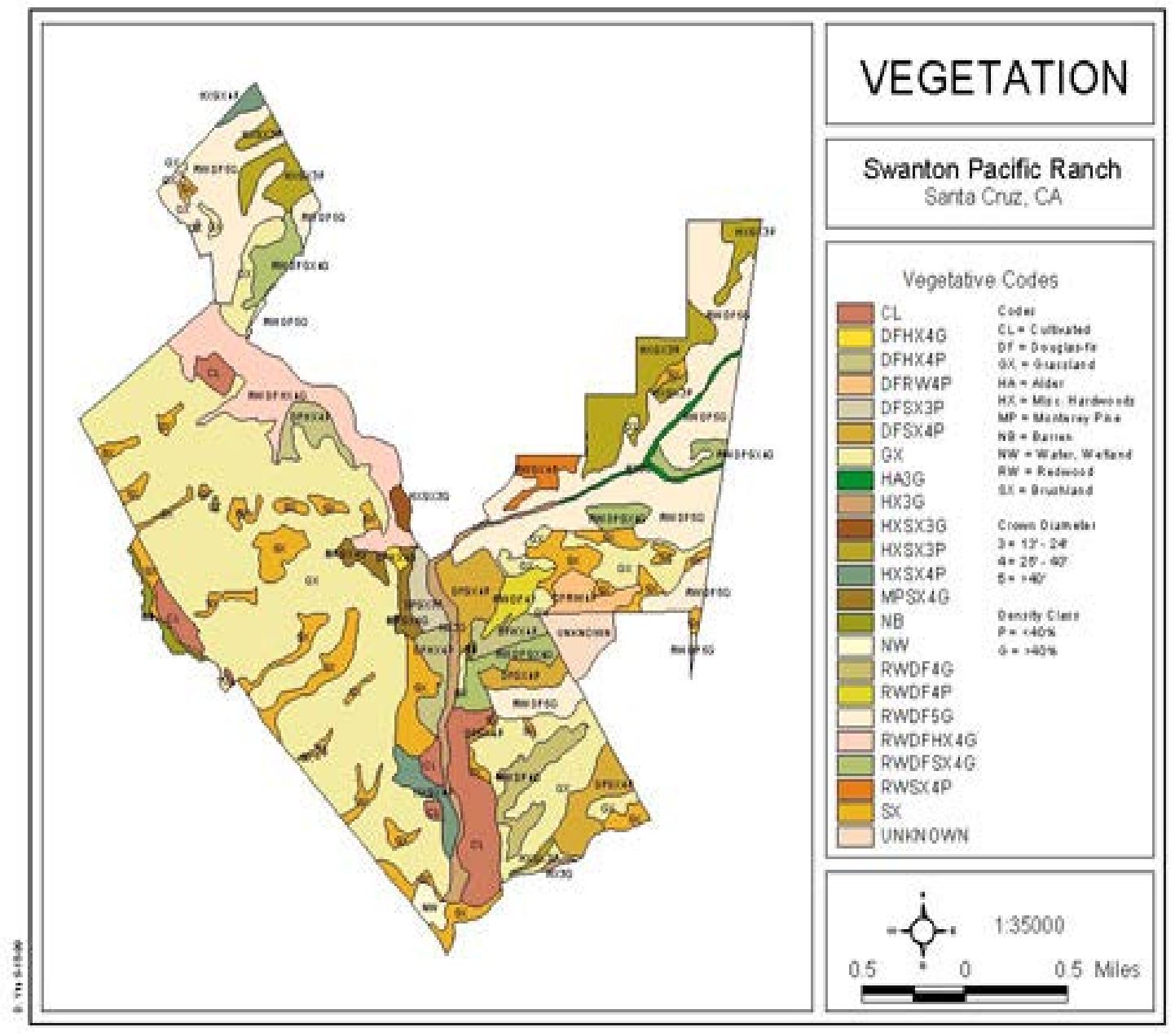

Figure 6. Vegetation map units of Swanton Pacific Ranch. Source: http://www.spranch.org/about.Idml 
Soils

The dominant soils mapped in Little Creek watershed consisted of Maymen

Stony Loam including rock outcrops, Ben Lomond/ Catelli/ Sur Complex, Santa Lucia

Loam, Lompico/ Felton Complex, and Bonny Doon Loam (Figure 7, Table 1).

Table 1. Soil Series names and Family Classifications of soils mapped in the Little Watershed. Soil Survey Staff, Natural Resources Conservation Service, United States Department of Agriculture. Official Soil Series Descriptions. Source: Soil Survey of Santa Cruz County, California

Soil Series Name Family Classification

\begin{tabular}{|c|c|}
\hline Ben Lomond/ & Coarse-loamy, mixed, superactive, mesic Pachic Ultic \\
\hline Catelli/ Sur & Haploxerolls/ Coarse-loamy, mixed, superactive, mesic Ultic \\
\hline Complex & $\begin{array}{l}\text { Haploxerolls/ Loamy-skeletal, mixed, superactive, mesic } \\
\text { Entic Haploxerolls }\end{array}$ \\
\hline Bonneydoon & $\begin{array}{l}\text { Loamy, mixed, superactive, thermic, shallow Entic } \\
\text { Haploxerolls }\end{array}$ \\
\hline Lompico/Felton & $\begin{array}{l}\text { Fine-loamy, mixed, superactive, mesic Ultic Argixerolls/ Fine- } \\
\text { loamy, mixed, superactive, mesic Ultic Argixerolls }\end{array}$ \\
\hline Maymen* & Loamy, mixed, active, mesic, shallow Typic Dystroxerepts \\
\hline Santa Lucia* & $\begin{array}{l}\text { Clayey-skeletal, mixed, superactive, thermic Pachic Ultic } \\
\text { Haploxerolls }\end{array}$ \\
\hline Soquel & Fine-loamy, mixed, active, mesic Cumulic Haploxerolls \\
\hline Tierra/ Watsonville & $\begin{array}{l}\text { Fine, smectitic, thermic Mollic Palexeralfs/ Fine, smectitic, } \\
\text { thermic Xeric Argialbolls }\end{array}$ \\
\hline Zyante & Sandy, mixed, mesic Humic Dystroxerepts \\
\hline
\end{tabular}

*Soil Series mapped within research sites. 


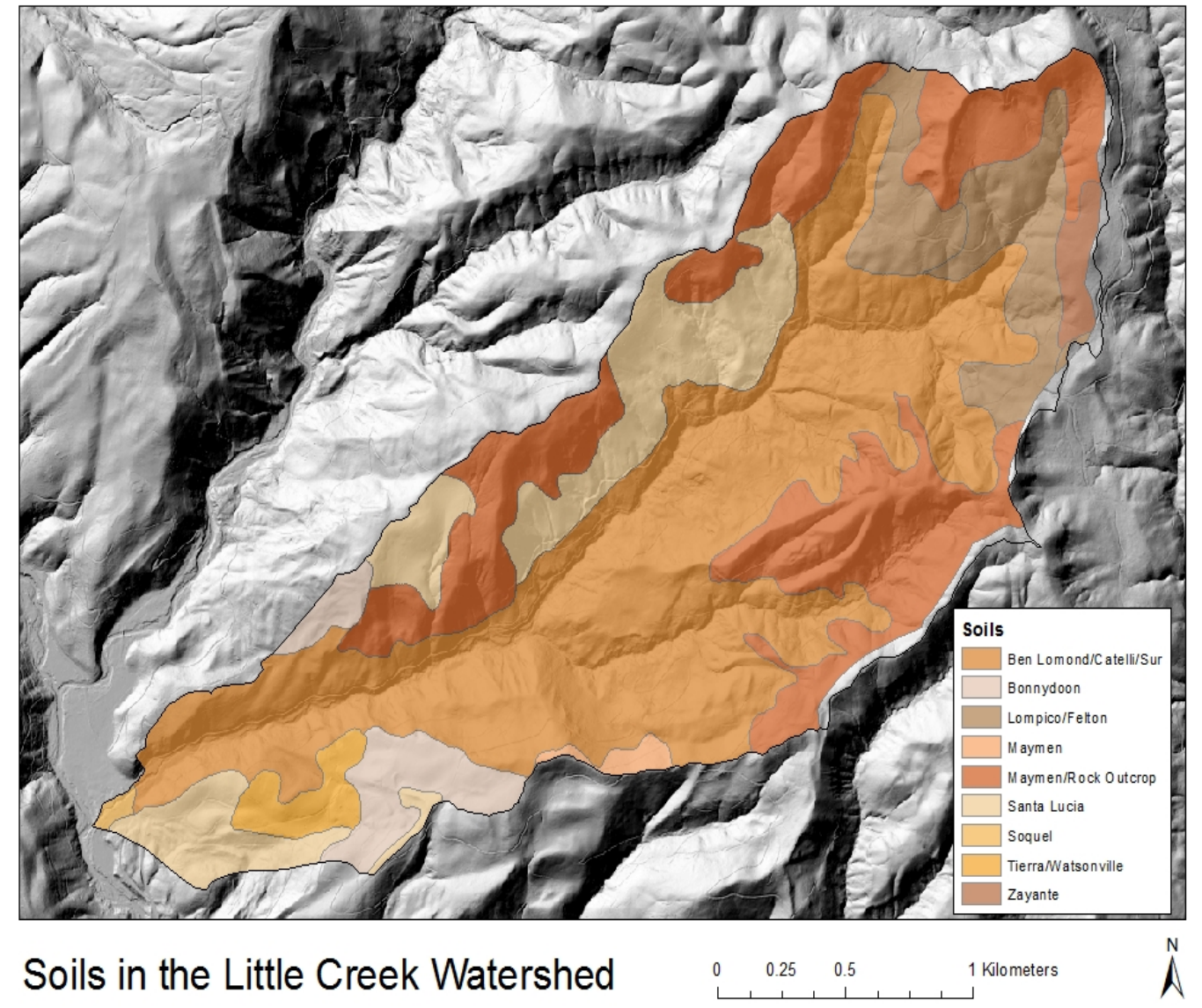

Figure 7. Series Map of Little Creek Watershed. Source: SSURGO

\section{Field Methods}

\section{Site Description}

The research sites selected were two hillslopes (Figure 8), approximately 3.4 hectares, located within the Lockheed Fire perimeter in the Little Creek watershed. The two hillslopes were primarily southeastern facing and the slope shape was planar convex. Slope steepness exceeded 40 percent and the slope length was extended up 
to $110 \mathrm{~m}$. The dominant bedrock underlying the two slopes was the Santa Cruz Mudstone and Santa Margarita sandstone (Figure 5). The vegetation consisted of a knobcone pine overstory with a mix chaparral understory on the summit and shoulder slopes and a mixed chaparral on the backslopes. The soil series mapped for these sites are the Maymen/ Maymen Rock Outcrop and the Santa Lucia (Figure 7). The BARC map and Lockheed Fire Incident Report indicated that the research area was moderate high to very high burn severity (Figure 2) (CalFire, 2009).

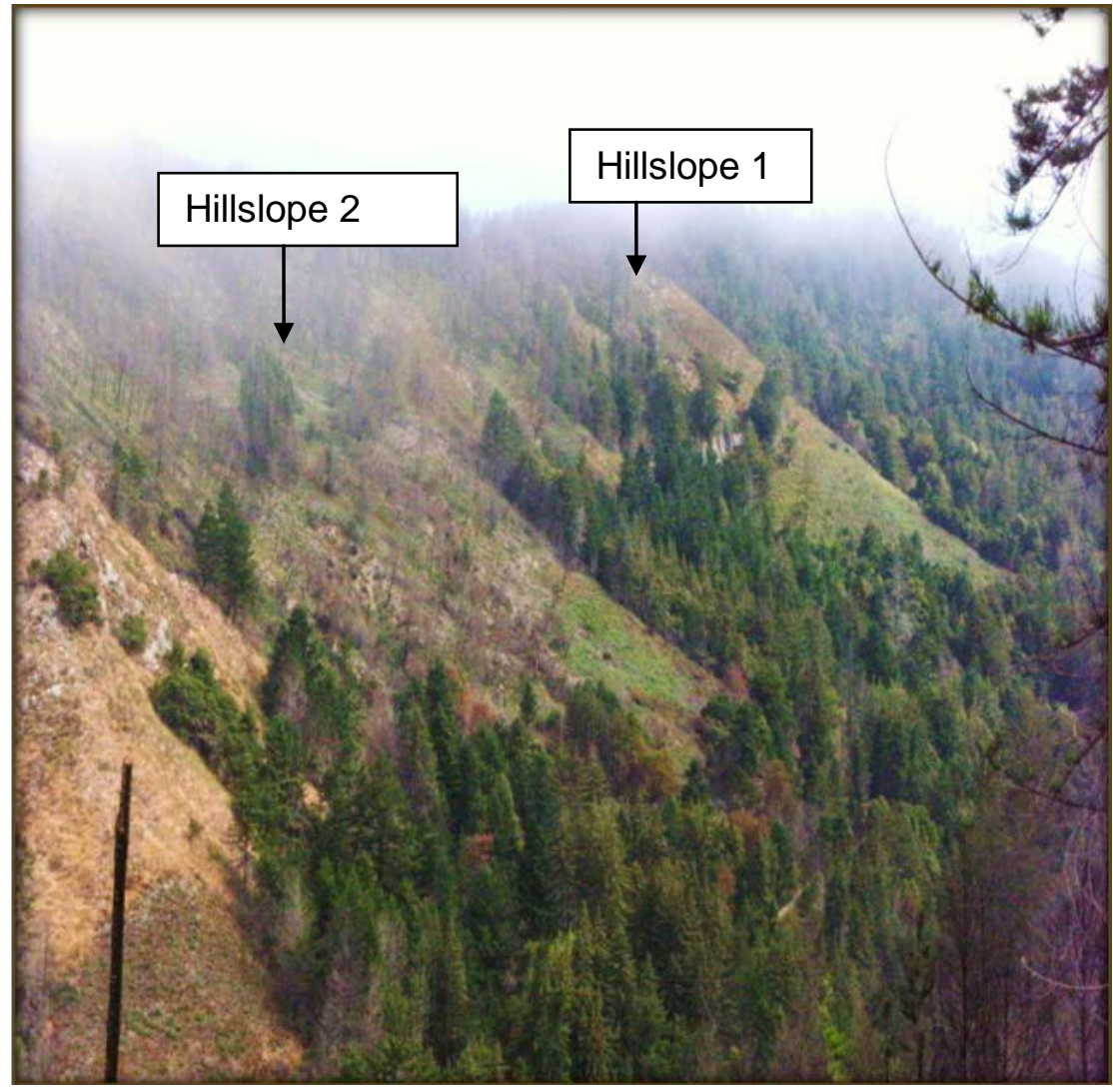

Figure 8. Photo of Hillslopes 1 and 2 at the time of sampling, nearly one year post fire $07 / 2010$. 


\section{Site Selection}

Eleven transects lines were established on the summit, shoulder, and backslope positions of the two hillslopes capturing the changes in site characteristics, geology, soil properties and the absence or presence of rill erosion (Figure 9). All transects were approximately $30 \mathrm{~m}$ in length and extended east to west along the contour of the hillslope. Random sample points were positioned along the transect line at $9 \mathrm{~m}, 18 \mathrm{~m}$ and $27 \mathrm{~m}$. A distance of $23 \mathrm{~m}$ was measured downslope between the transect lines to obtain a slope length. The actual slope length distance varied between 15 and $23 \mathrm{~m}$ as topography would permit.

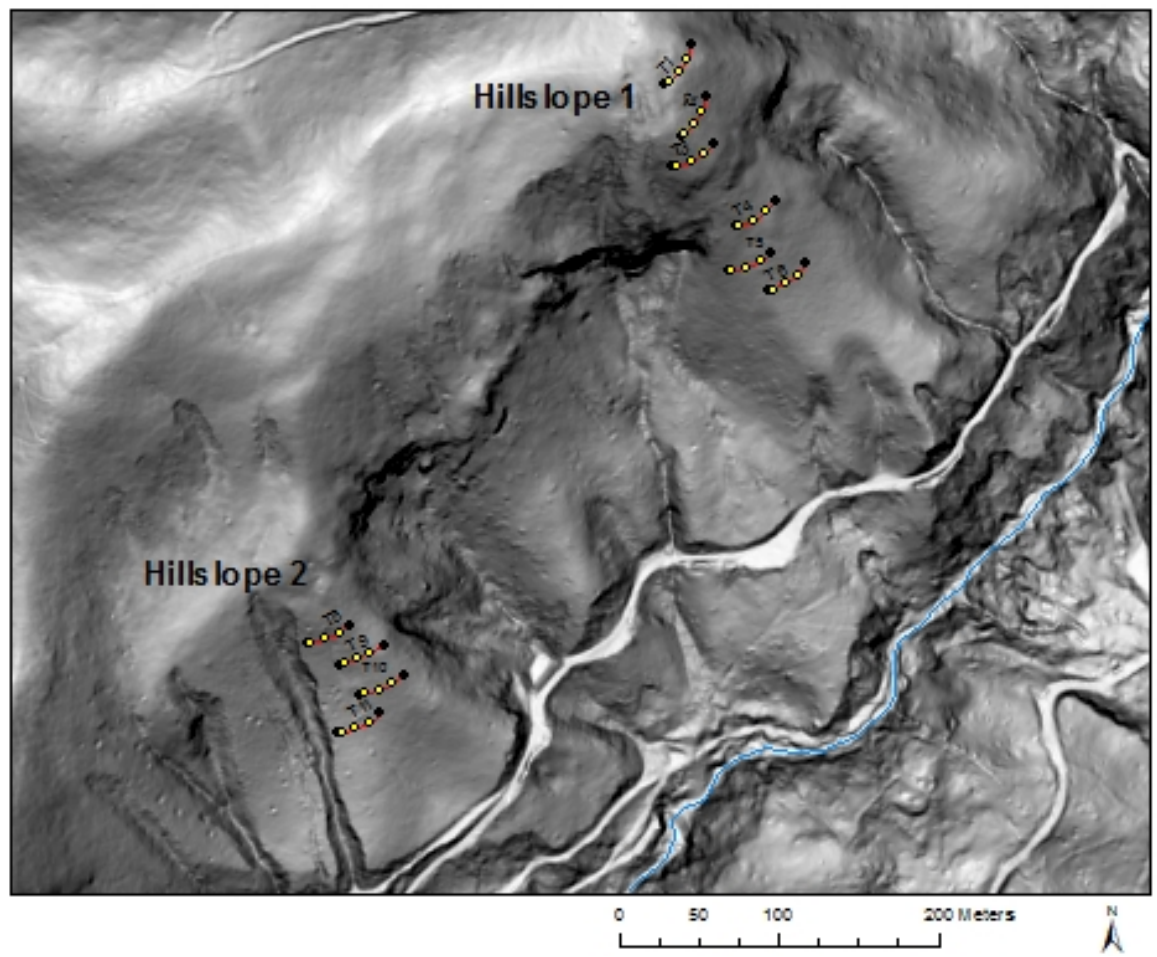

Figure 9. Study Location, Two hillslopes above Little Creek. The black dots represent the transect beginning and end of Transect lines T1-T11.T7 was dismissed from the research; therefore the site location is not indicated on this map. The yellow dots indicate sample points (9 $\mathrm{m}, 18 \mathrm{~m}$ and $27 \mathrm{~m}$ ) along each $30 \mathrm{~m}$ transect line. 


\section{Sampling}

\section{Site Characteristics}

At each transect, site characteristics (aspect, slope steepness, slope shape, and slope length) were assessed and recorded. Slope steepness was measured in percent with a clinometer. Slope aspect was measured in degrees with a standard azimuth compass. A visual assessment was used to determine whether the planar slope shape was convex or concave. Slope length was determined with the use of GPS points and GIS and a $100 \mathrm{~m}$ tape was used to obtain spacing distance of 15 to 23 $\mathrm{m}$ downslope between each transect. Elevation, latitude and longitude coordinates were recorded using a Garmin GPS unit.

\section{Soil Characteristics}

Two soil profiles were described on each hillside at representative locations, and hand excavated soil pits were described using standard methods (Soil Survey Staff, 2000). Approximately 200 grams of soil were collected from each soil horizon of the soil pedon. The samples were placed into plastic bags, and then transported to the lab for analyses. The soil sampling procedures were designed to capture the site and soil characteristic from both non-rilled and rilled locations within the burned area. Soil samples were collected at a depth of 1 to $3 \mathrm{~cm}$ from points along the transect lines. A total of 30 soil samples were collected from rilled and non-rilled sites. Transect points, T7 was eliminated due to the introduction of new confounding variables, therefore three samples were discarded. 
Characteristics measured in the field

\section{Water Repellency}

The Water Drop Penetration Test (WDPT) was also administered at the established sample point along the transect line. The sample area was prepared by clearing the ash and organic matter aside and exposing mineral soil. A water drop was applied to the soil surface at 1 and $3 \mathrm{~cm}$ depth and the residence time of the water drop to infiltrate was recorded. The classification to determine the degree of water repellency was taken from the USFS BAER procedures, and threshold class of WDPT: $<10$ s (weak), 10- 40 s (moderate), and >40 s (strong) (Robichaud et al., 2008).

Infiltration (MDI)

Infiltration measurements were also taken at each established sample point along the transects (at 9, 18 and $27 \mathrm{~m}$ ) by using the Mini Disk Infiltrometer ${ }^{\mathrm{TM}}$ (MDI) (Decagon Devices, Inc., Pullman, WA). The procedures used for these measurements were taken from Robichaud et al., 2008. The suction of the MDI was adjusted to $1 \mathrm{~cm}$, which is the suggested setting for post fire soil infiltration to provide capillarity suction and maintain a constant pressure while keeping the instrument from leaking (Decagon Devices, Inc., Pullman, WA). Each sampling was prepared by brushing away any remaining ash or litter layer down to $1 \mathrm{~cm}$ and $3 \mathrm{~cm}$ below the mineral soil surface. The instrument was filled with water and place on the mineral soil for duration of 1 minute. The volume of water that infiltrated within 1 minute was recorded. This test was then replicated three times at each depth adjacent to the other test and never on top of or below a previous test. 


\section{Saturated Hydraulic Conductivity $\left(\mathrm{K}_{\mathrm{sat}}\right)$}

A Constant Head Permeameter (CHP) was used to measure the saturated hydraulic conductivity $\left(\mathrm{K}_{\mathrm{sat}}\right)$ of the soil. This instrument measures the rate of which water moves through the soil in inches per hour (in/hr). At each sample location along the established transects, a bore hole of 13 to $15 \mathrm{~cm}$ depth was hammered into the ground using a metal pipe that was slightly larger in diameter than the CHP of the instrument. The CHP was then filled with water and carefully placed in the hole that was created. An acrylic spacer ring was placed between the soil surface and the CHP lifting the device $1 / 4$ in above the hole for stability. The flow valve to the CHP was then opened for approximately 5 minutes or until the falling water level indicated a consistent rate of infiltration. The amount of time and change in water level was recorded to determine the ( $\left.\mathrm{K}_{\text {sat }}\right)$ (Loftis, NRCS, Personal Communication, 2010).

\section{Laboratory Methods}

\section{Soil Texture and Dispersion}

The standard ASTM (American Society for Testing and Materials) method following chemical and mechanical distribution was used for calculating particle size analysis (Gee and Orr, 2002). Particle size distribution was determined by hydrometer and sieve, directly following pretreatment and dispersal. Pretreatment consisted of organic matter removal with 35 percent hydrogen peroxide.

Dispersivity was determined by using the "Double Hydrometer Test" (Volk, 1937; Sherard et al., 1976). Dispersion quantifies the soils tendency to disperse 
without chemical and mechanical dispersion agent. Soil samples of $50 \mathrm{~g}$ were placed onto watch glasses and DI water added until soil aggregates were moistened by capillarity. The samples were then placed in sedimentation cylinders for hydrometer readings, which were taken along side readings for particle size analysis. Dispersion ratio was calculated as percent finer than $0.005 \mathrm{~mm}$ diameter naturally dispersed and finer than $0.005 \mathrm{~mm}$ diameter mechanically and chemically dispersed

\section{Organic Carbon and Nitrogen}

A representative portion of each sample was passed through a No.10 sieve, and then finely ground. Approximately $1 \mathrm{~g}$ was weighed and placed in the Vario Max analyzer and the carbon and nitrogen were measured using the CNS. This procedure detected the percent organic total carbon and nitrogen within the soil. This instrument combusted the carbon in each sample and measured the evolved $\mathrm{CO}_{2}$, then calculated the percent carbon in each sample.

\section{Statistical Analysis of Data}

Binary logistical regression was performed to determine the probability of rill occurrence. The presence or absence of rill erosion was the dependent variable. The independent variables were infiltration at $1 \mathrm{~cm}$ and $3 \mathrm{~cm}, \log _{10}\left(\mathrm{~K}_{\mathrm{sat}}\right)$, clay percent, slope length, slope percent, organic matter percent, dispersion ratio, and water repellency (as evaluated by WDPT). 


\section{CHAPTER 4}

Results

Landscape Characteristic

Topographic characteristics for non-rilled and rilled areas on both hillslopes are listed in Table 2. All non-rilled sites were on either summit and shoulder or shoulder and backslope positions (Figure 10a and 11a). Slope steepness ranged between 45 and 83 percent, with a slope length $\leq 85 \mathrm{~m}$. The non-rilled sites consisted of highlyfractured mudstone residuum and the vegetation was composed of a knobecone pine overstory and mixed chaparral community.

Rilled transects were positioned on the backslopes, on slopes between 45 to 80 percent, and slope lengths were $\leq 198 \mathrm{~m}$ (Figure 10b and 11b). These transect were colluvium derived from mudstone and fraction of sandstone. The vegetation was composed of a mixed Chaparral community. A post-fire plant identification list is in Appendix A.

Table 2. Landscape Characteristics of the two Hillslopes and transect lines with the presence and absence of rill erosion.

\begin{tabular}{llllllll}
\hline Hillslope & $\begin{array}{l}\text { Presence } \\
\text { of Rill } \\
\text { Erosion }\end{array}$ & $\begin{array}{l}\text { Hillslope } \\
\text { Position }\end{array}$ & $\begin{array}{l}\text { Aspect } \\
\text { degrees }\end{array}$ & $\begin{array}{l}\text { Elevation } \\
(\mathrm{m})\end{array}$ & $\begin{array}{l}\text { Planar } \\
\text { Slope } \\
\text { Shape }\end{array}$ & $\begin{array}{l}\text { Slope } \\
\text { Length } \\
(\mathrm{m})\end{array}$ & $\begin{array}{l}\text { Slope } \\
\text { Steepness } \\
(\%)\end{array}$ \\
\hline 1 & No & $\begin{array}{l}\text { Summit/ } \\
\text { Shoulder }\end{array}$ & $125 \mathrm{SE}$ & $367-388$ & Convex & 85 & $45-83$ \\
1 & Yes & $\begin{array}{l}\text { Backslope } \\
\text { Shoulder/ }\end{array}$ & $150 \mathrm{SE}$ & $294-321$ & Convex & 198 & $60-80$ \\
2 & No & $\begin{array}{l}\text { Shockslope } \\
\text { Back }\end{array}$ & 258-271 & Convex & 69 & $67-80$ \\
2 & Yes & Backslope & $150 \mathrm{SE}$ & $234-247$ & Convex & 108 & $45-75$ \\
\hline
\end{tabular}



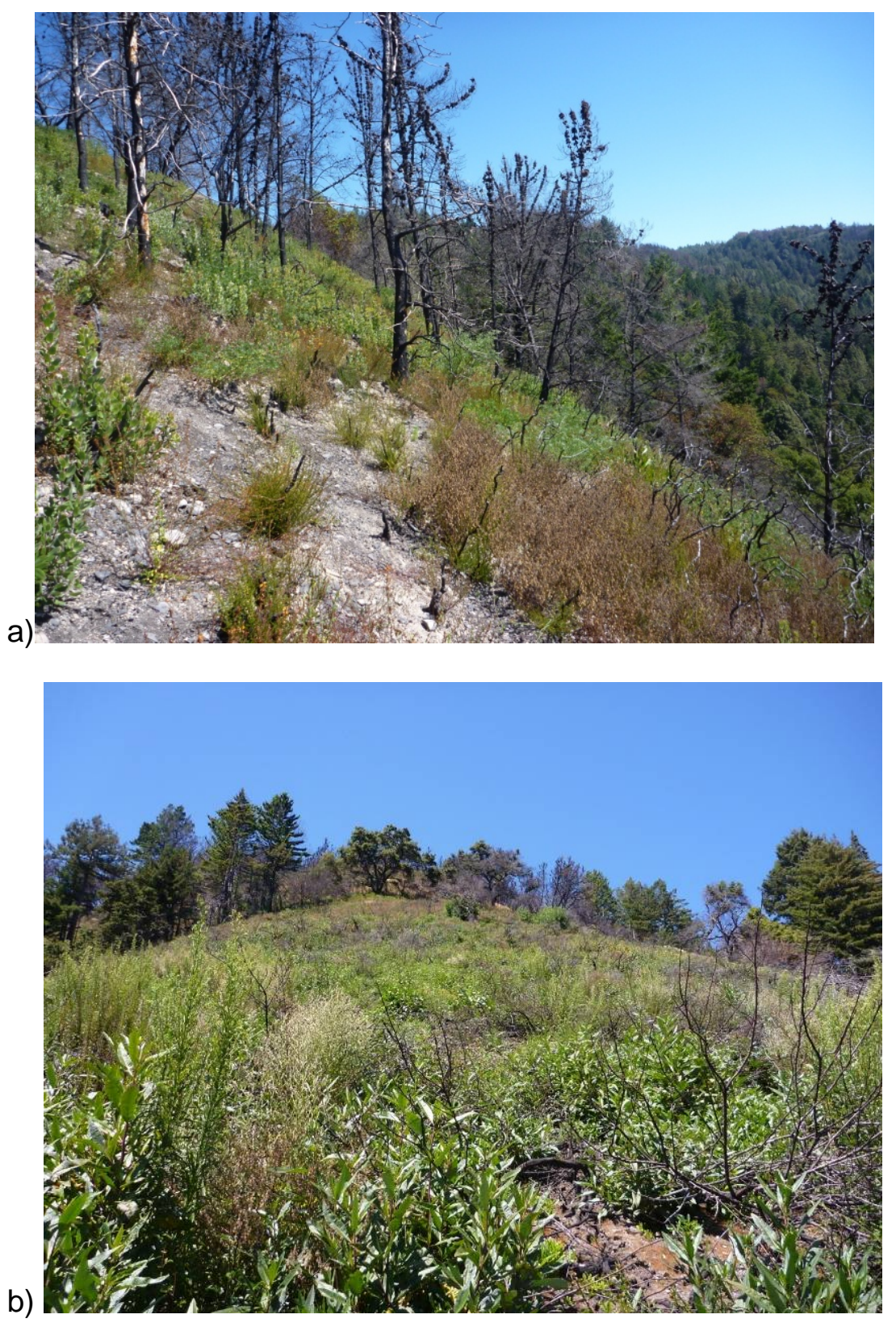

Figure 10. Hillslope 1, a) Non-rilled sites transects T1- T3, Summit and Shoulder slope. b) Rilled sites transects T4-T6, on backslope. 

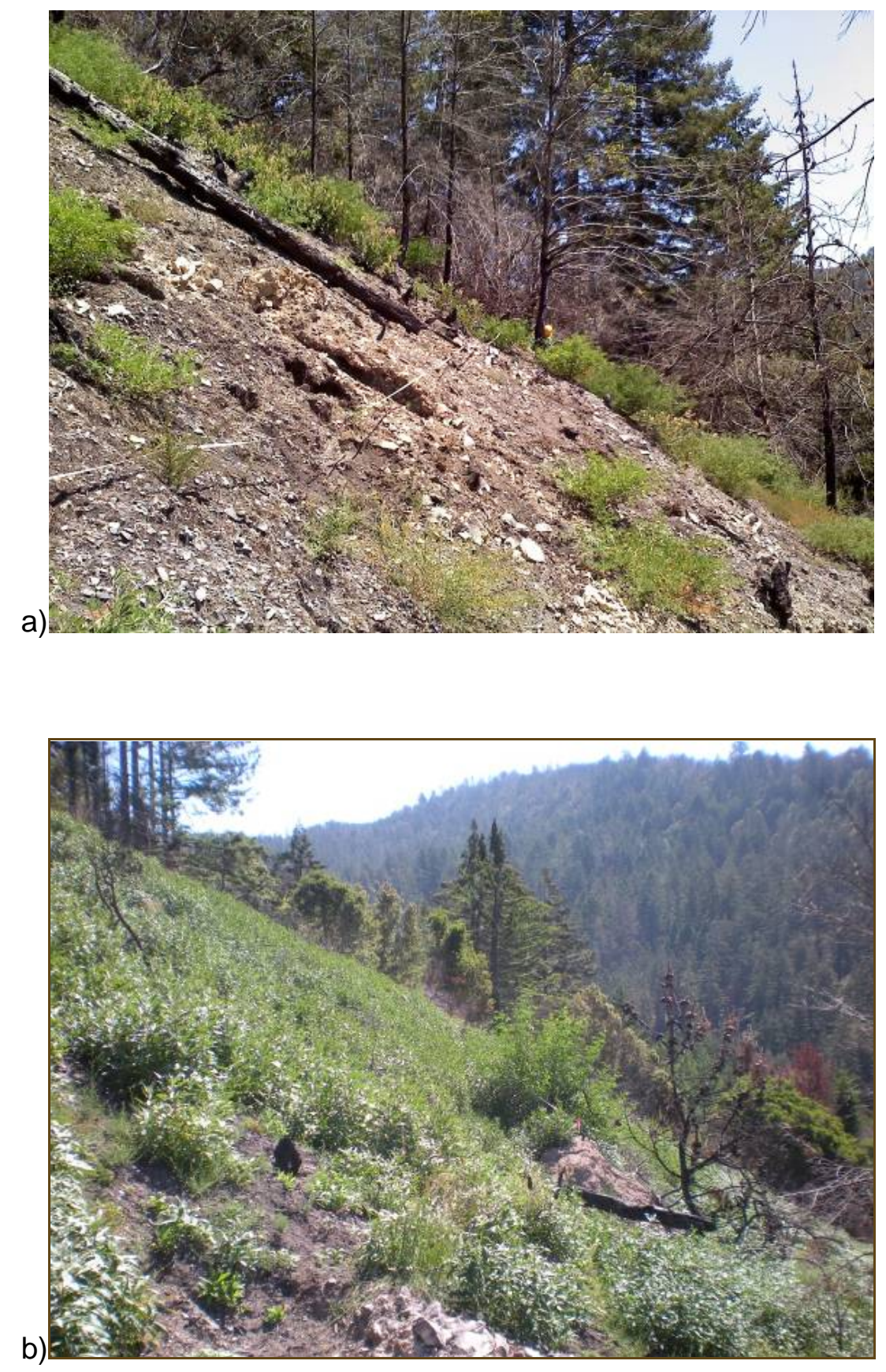

Figure 11. Hillslope 2, a) Shoulder slope no rill erosion, transect T9. b) Rilled sites located on the backslope photo taken between transect T10 and T11. 


\section{Soil Characteristics}

The non-rilled soils identified from the pedon profile description were Lithic Haploxerepts. The non-rilled soils displayed poorly developed A horizons with soil depth less than $10 \mathrm{~cm}$, transitioned into a $\mathrm{C}$ and a $\mathrm{Cr}$ horizon, a highly fractured mudstone residuum (Pedon 1 and 4, Appendix C). Rilled transects on hillslope 1 were classified as Typic Haploxerolls and the rilled transects on hillslope 2 were identified as Typic Argixerolls. Soils on both rilled transects were developed in colluvium derived mudstone with a fraction of sandstone (Pedon 2 and 4, Appendix C).

Non-rilled soil surface textures were loam and sandy clay loam (Table 3). The average clay content for non-rilled sites was 22 percent. These non-rilled locations also contained a high quantity of surface rock fragment ranging from 65 to 85 percent the ground cover. The rilled transect surface textures were more variable, consisting of loam, sandy clay loam, sandy loam and clay loam, with an average clay content of 23 percent (Table 3). The surface rock fragments observed for rilled transects locations had a range of 30 to 65 percent cover. 
Table 3. Soil characteristics for non-rill and rill erosion transect sample sites.

\begin{tabular}{|c|c|c|c|c|c|c|c|}
\hline \multirow{2}{*}{$\begin{array}{l}\text { Hillslope } \\
1\end{array}$} & \multirow{2}{*}{$\begin{array}{l}\text { Presence } \\
\text { of Rill } \\
\text { Erosion } \\
\text { No }\end{array}$} & \multicolumn{2}{|c|}{$\begin{array}{l}\text { Transect } \\
\text { Number }\end{array}$} & Surface Texture & $\begin{array}{l}\text { Sand } \\
\text { (\%) }\end{array}$ & $\begin{array}{l}\text { Clay } \\
(\%)\end{array}$ & \multirow[t]{2}{*}{$\begin{array}{l}\text { Dispersion } \\
\text { Ratio }\end{array}$} \\
\hline & & T1 & 30 & loam & 41 & 16 & \\
\hline & & & 60 & loam & 35 & 20 & 0.17 \\
\hline & & & 90 & loam & 37 & 22 & 0.18 \\
\hline & & $\mathrm{T} 2$ & 30 & loam & 28 & 28 & 0.14 \\
\hline & & & 60 & loam & 38 & 16 & 0.16 \\
\hline & & & 90 & loam & 33 & 20 & 0.12 \\
\hline & & T3 & 30 & loam & 39 & 21 & 0.07 \\
\hline & & & 60 & loam & 41 & 23 & 0.12 \\
\hline & & & 90 & loam & 38 & 24 & 0.06 \\
\hline \multirow[t]{6}{*}{2} & & T8 & 30 & loam & 41 & 23 & 0.08 \\
\hline & & & 60 & sandy clay loam & 51 & 23 & 0.10 \\
\hline & & & 90 & sandy clay loam & 50 & 21 & 0.08 \\
\hline & & T9 & 30 & loam & 32 & 28 & 0.12 \\
\hline & & & 60 & loam & 40 & 24 & 0.10 \\
\hline & & & 90 & loam & 35 & 17 & 0.10 \\
\hline \multirow[t]{9}{*}{1} & Yes & T4 & 30 & loam & 43 & 25 & 0.06 \\
\hline & & & 60 & sandy clay loam & 48 & 28 & 0.18 \\
\hline & & & 90 & sandy clay loam & 50 & 27 & 0.04 \\
\hline & & T5 & 30 & sandy loam & 59 & 19 & 0.08 \\
\hline & & & 60 & loam & 43 & 25 & 0.12 \\
\hline & & & 90 & loam & 42 & 26 & 0.05 \\
\hline & & T6 & 30 & loam & 47 & 21 & 0.16 \\
\hline & & & 60 & sandy loam & 52 & 20 & 0.12 \\
\hline & & & 90 & sandy loam & 54 & 15 & 0.13 \\
\hline \multirow[t]{6}{*}{2} & & $\mathrm{~T} 10$ & 30 & sandy clay loam & 53 & 22 & 0.05 \\
\hline & & & 60 & clay loam & 39 & 30 & 0.04 \\
\hline & & & 90 & loam & 41 & 24 & 0.07 \\
\hline & & T11 & 30 & loam & 32 & 27 & 0.05 \\
\hline & & & 60 & loam & 36 & 21 & 0.13 \\
\hline & & & 90 & loam & 43 & 20 & 0.09 \\
\hline
\end{tabular}




\section{Organic Carbon and Nitrogen}

The organic carbon concentration for non rilled transects varied between 2.55 and 6.94 percent at the surface; on the rilled sites, carbon ranged from 2.07 to 6.44 percent. Nitrogen concentration on non-rilled sites varied between 0.113 and 0.384 percent. In rilled transects, the nitrogen concentrations fluctuated between 0.188 and 0.494 percent The mean nitrogen percent for all transects are presented in Table 4.

Table 4. The mean with a standard deviation based on the sample value for Organic Matter, Carbon and Nitrogen percent and the Carbon/Nitrogen ratio of both hillslopes with and without the presence of rill erosion.

\begin{tabular}{lllllll}
\hline Hillslope & $\begin{array}{l}\text { Presence } \\
\text { of Rilling }\end{array}$ & $\begin{array}{l}\text { Transect } \\
\text { Number }\end{array}$ & $\begin{array}{l}\text { Organic } \\
\text { Matter } \\
(\%)\end{array}$ & $\begin{array}{l}\text { Mean } \\
\text { Carbon } \\
(\%)\end{array}$ & $\begin{array}{l}\text { Mean } \\
\text { Nitrogen } \\
(\%)\end{array}$ & $\begin{array}{l}\text { Mean } \\
\text { Carbon/ } \\
\text { Nitrogen }\end{array}$ \\
\hline 1 & No & T1 & $8.0 \pm 2.3$ & $4.0 \pm 1.2$ & $0.2 \pm 0.1$ & $23.4 \pm 2.6$ \\
& & T2 & $6.8 \pm 1.5$ & $3.4 \pm 0.7$ & $0.2 \pm 0.0$ & $20.5 \pm 0.9$ \\
& & T3 & $11.4 \pm 1.5$ & $5.7 \pm 0.7$ & $0.3 \pm 0.0$ & $17.3 \pm 1.0$ \\
2 & & T8 & $8.4 \pm 1.2$ & $4.2 \pm 0.6$ & $0.2 \pm 0.0$ & $22.5 \pm 2.4$ \\
1 & \multirow{3}{*}{ Yes } & T9 & $10.9 \pm 2.7$ & $5.4 \pm 1.4$ & $0.3 \pm 0.1$ & $18.4 \pm 1.2$ \\
& & T4 & $12.5 \pm 0.5$ & $6.2 \pm 0.2$ & $0.4 \pm 0.0$ & $14.0 \pm 0.8$ \\
& & T5 & $11.8 \pm 2.3$ & $5.9 \pm 1.2$ & $0.4 \pm 0.1$ & $15.8 \pm 0.4$ \\
2 & & T6 & $6.5 \pm 1.1$ & $3.3 \pm 0.5$ & $0.2 \pm 0.0$ & $14.6 \pm 0.3$ \\
& & T10 & $13.1 \pm 2.8$ & $6.6 \pm 1.4$ & $0.4 \pm 0.1$ & $16.4 \pm 0.3$ \\
& & T11 & $10.5 \pm 2.4$ & $5.2 \pm 1.2$ & $0.3 \pm 0.1$ & $16.3 \pm 1.0$ \\
\hline
\end{tabular}




\section{Water Repellency WDPT}

The WDPT test, as a measure of water repellency, was performed at $1 \mathrm{~cm}$ and $3 \mathrm{~cm}$ depths at each sample point (site) on non-rilled and rilled transects. The water repellent soils had predominantly weak repellency for both non-rilled and rilled sites. On the non-rilled sites at both 1 and $3 \mathrm{~cm}$ depth, 60 percent of the observed tests were weakly water repellent. At the $1 \mathrm{~cm}$ depth, 33 percent of the sites showed moderate repellency. The T2 (30) sample point, non-rilled, showed strong water repellency. At the $3 \mathrm{~cm}$ depth, 13 percent of the sites showed moderate water repellency and 27 percent of the sites showed strong repellency. All these results are shown on Figure 12.

Likewise, the majority of sites on rilled transects showed weak water repellency. At the $1 \mathrm{~cm}$ depth, 80 percent of the sites showed weak repellency. At the $3 \mathrm{~cm}$ depth 60 percent of the sites showed weak water repellency. Only site T6 (30) showed

moderate water repellency at $1 \mathrm{~cm}$. At the $3 \mathrm{~cm}$ depth, moderate repellency was displayed in 27 percent of the sites. Strong water repellency was displayed in 13 percent of the tests at 1 and $3 \mathrm{~cm}$ depths (Figure 12). 

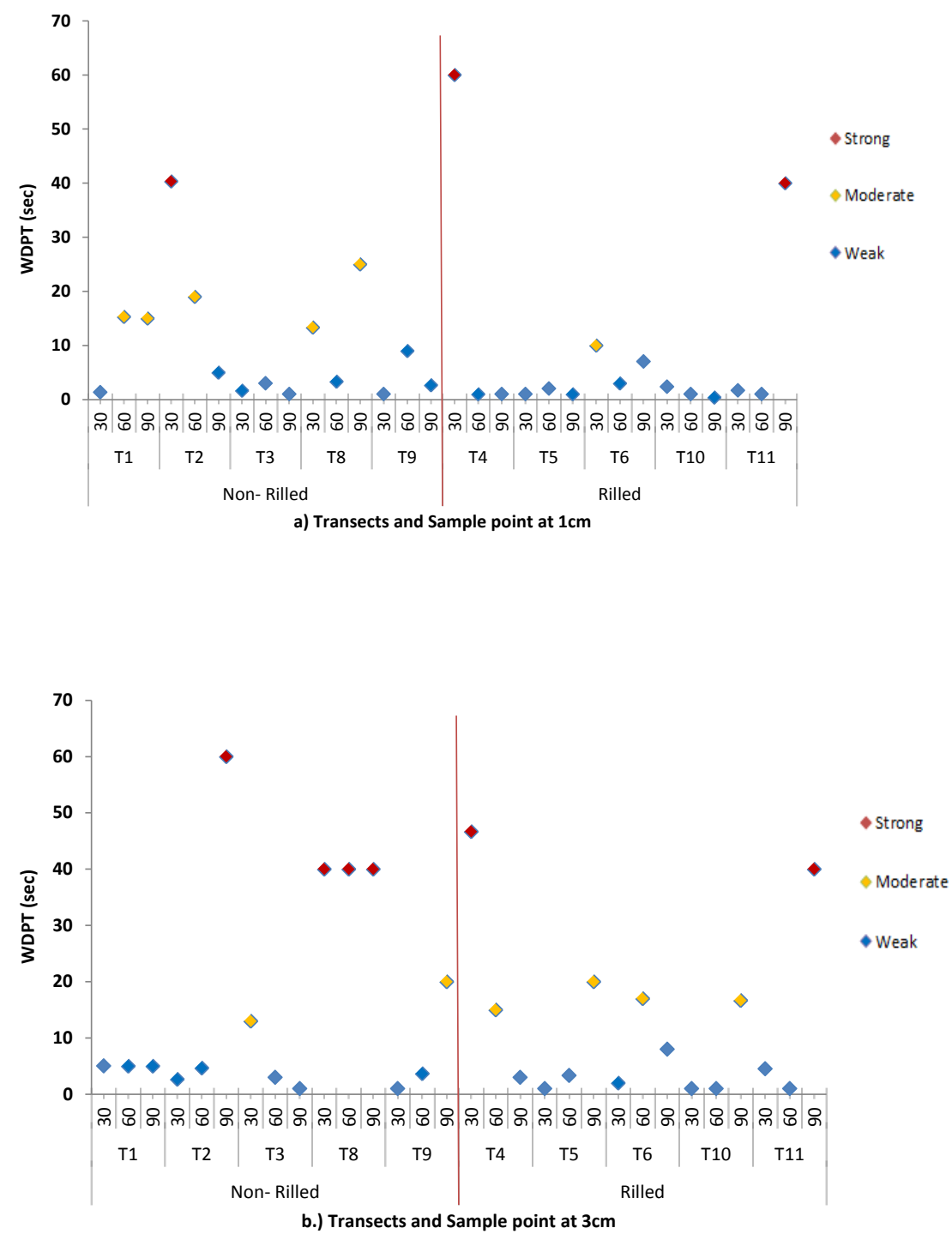

Figure 12. Mean soil water repellency at a depth of $1 \mathrm{~cm}$ and $3 \mathrm{~cm}$ at transect sample locations (30,60 and 90ft). Higher values colored red indicate strong repellency (>40sec), Yellow indicates moderate repellency ranging from 10-40 sec, Lower blue values are designate weak repellency $(<10 \mathrm{sec})$. 
Infiltration

Infiltration with the mini disk infiltrometer was measured at depths of 1 and 3 $\mathrm{cm}$. At each sample location and each depth, three measurements were made. To obtain a relatively homogeneous infiltration rate, due to the spatial variability in infiltration, at each sample location the three tests were averaged at each site on each transect (Figure 13).

Non-rilled transects T1, T2 and T3 had an infiltration that varied between 0.1 to $29.5 \mathrm{~mL} \mathrm{~min}^{-1}$ at 1 and $3 \mathrm{~cm}$. The $8.7 \mathrm{~mL} \mathrm{~min}^{-1}$ infiltration mean at $1 \mathrm{~cm}$ was higher than the mean at $3 \mathrm{~cm}, 5.26 \mathrm{~mL} \mathrm{~min}^{-1}$. At transects T8 and T9 hillslope 2 infiltration was not lower at the $3 \mathrm{~cm}$ depth compared to $1 \mathrm{~cm}$. T8 and T9 infiltration varied from 0.1 to 15 $\mathrm{mL} \min ^{-1}$ (mean,2.2 $\mathrm{mL} \mathrm{min}^{-1}$ ) at $1 \mathrm{~cm}$ and $0-22.0 \mathrm{~mL} \mathrm{~min}^{-1}$ at $3 \mathrm{~cm}$ (mean,4.11 $\mathrm{mL}$ $\min ^{-1}$ ) (Figure 13c).

The rilled transects T4, T5, and T6 (hillslope 1) there was a greater range in infiltration, varying between 1.0 to $46.0 \mathrm{~mL} \mathrm{~min}^{-1}$ at $1 \mathrm{~cm}$ (mean of $15.5 \mathrm{~mL} \mathrm{~min}^{-1}$ ). Infiltration the $3 \mathrm{~cm}$ depth showed less variation compared to $1 \mathrm{~cm}$, ranging between 1.0 to $22.5 \mathrm{~mL} \mathrm{~min}^{-1}$ (mean of $6.5 \mathrm{~mL} \mathrm{~min}^{-1}$ ) Infiltration rates at rilled transects $\mathrm{T} 10$ and T11, located on hillslope 2, ranged between 0.01 to $27.5 \mathrm{~mL}$ min- ${ }^{1}$ with a mean infiltration rate of $6.4 \mathrm{~mL} \mathrm{~min}^{-1}$. Like the rilled transects on hillslope 1 , infiltration at the lower depth of $3 \mathrm{~cm}$ was lower ranging between 0.01 to $22 \mathrm{~mL} \mathrm{~min}^{-1}$ (mean of $3.94 \mathrm{~mL}$ $\left.\min ^{-1}\right)$. 

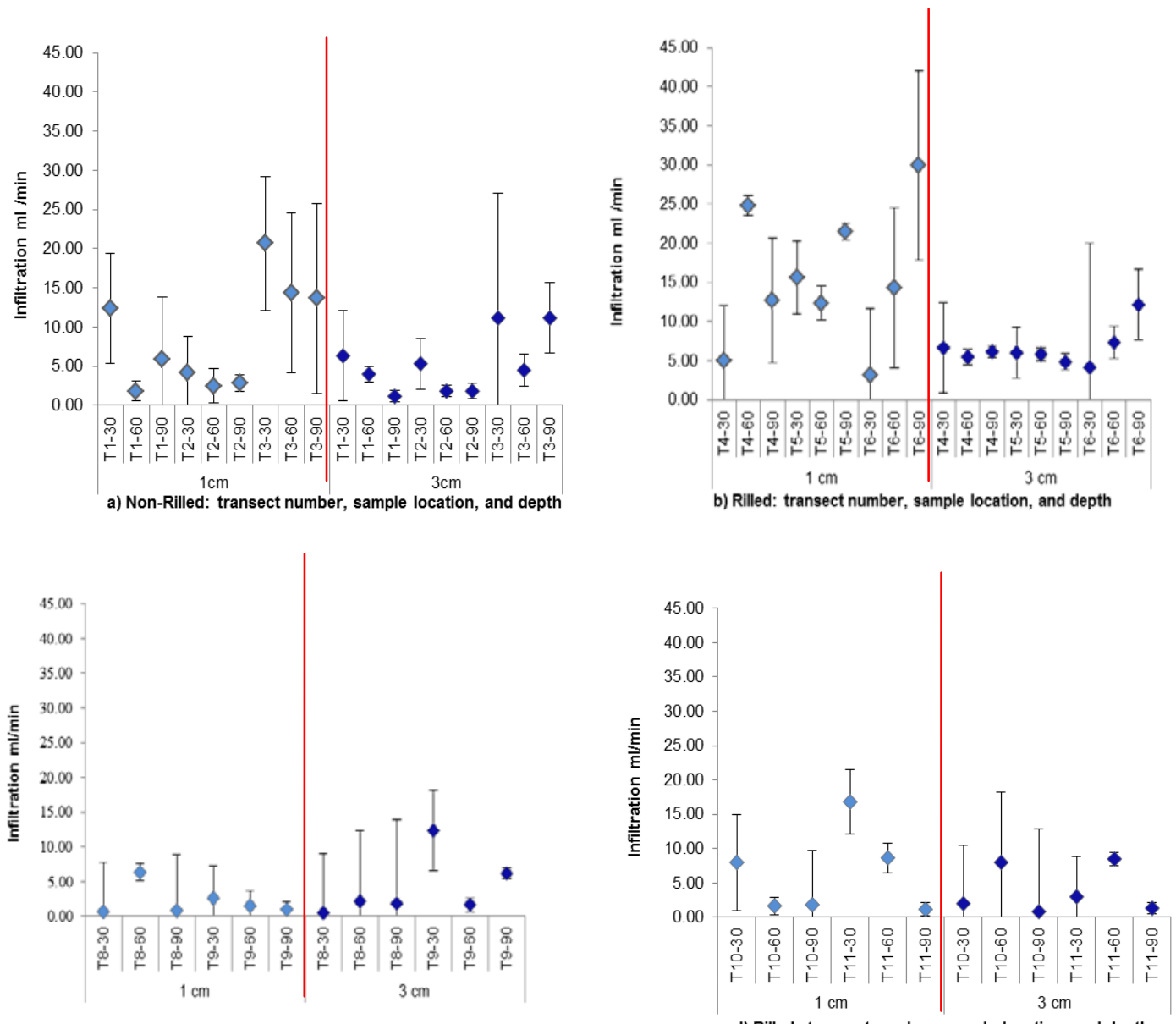

c) Non- Rilled: transect number, sample location, and depth

d) Rilled: transect number, sample location, and depth

Figure 13. Mean soil water infiltration $\mathrm{ml} / \mathrm{min}$ verses $1 \mathrm{~cm}$ and $3 \mathrm{~cm}$ depth for transect site locations; a) Non-rilled T1,T2 and T3, b) Rilled T4,T5 and T6, c) Non-rilled T8 and T9, d) Rilled T10 and T11. Light blue indicates $1 \mathrm{~cm}$ infiltration; dark blue indicates 3 $\mathrm{cm}$ infiltration rates with error bars representing variability in the measurements at a standard deviation. 


\section{Saturated Hydraulic conductivity $\left(\mathrm{K}_{\text {sat }}\right)$}

Saturated Hydraulic conductivity ( $\left.\mathrm{K}_{\mathrm{sat}}\right)$ at a depth of 12 to $15 \mathrm{~cm}$ of the soil on non-rilled sites showed a higher $\left(\mathrm{K}_{\text {sat }}\right)$ than rilled sites. The mean $\left(\mathrm{K}_{\text {sat }}\right)$ was 70.51 $\mathrm{cm} / \mathrm{hr}$ (median $64.59 \mathrm{~cm} / \mathrm{hr}$ ); with a range of 5.77 to $326.57 \mathrm{~cm} / \mathrm{hr}$. Rilled transects exhibited a lower $\left(\mathrm{K}_{\mathrm{sat}}\right)$ mean $34.54 \mathrm{~cm} / \mathrm{hr}$ (median, $24.18 \mathrm{~cm} / \mathrm{hr}$ ), with a range of 1.07 to119.08 cm/hr.

$\left(\mathrm{K}_{\mathrm{sat}}\right)$ displayed a wide range of readings; therefore a $\log _{10}$ transformation was used to establish a normal distribution in the data (Figure 14).

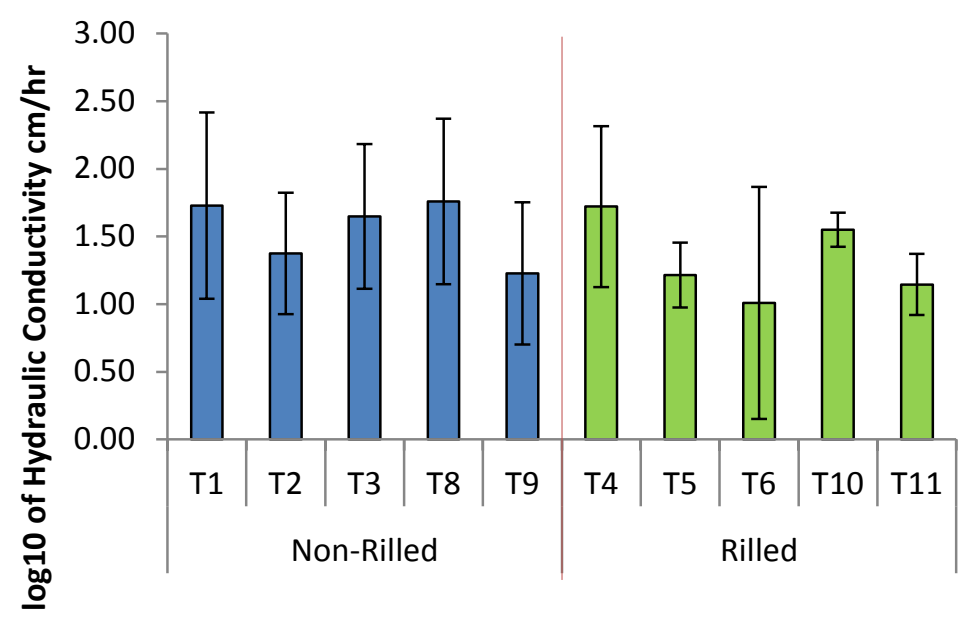

Transect Number

Figure 14. $\log 10$ Saturated Hydraulic Conductivity $\left(\mathrm{K}_{\mathrm{sat}}\right) \mathrm{cm} / \mathrm{hr}$ mean values are presented with error bars as \pm 1 SD (1 standard deviation). Non rilled transects represented by blue bars and rilled are represented by green bars. 
Statistical Analysis of Data

The statistical evaluation recognized significant variables contributing to rill occurrence, but did not identify individual strong relationships between the significant key variables. The binary logistic regression identified that 91 percent of the variability of the data observed accounted for the rilling that occurred when these variables were combined. In the preliminary trials applying the binary logistic regression, organic matter percent, dispersion ratio, and water repellency were not statistically significant; therefore they were eliminated as variables. Statistical evaluation recognized the key variables controlling the occurrence of rill erosion as follow: clay content, $1-3 \mathrm{~cm}$ infiltration rates, slope length, slope percent and hydraulic conductivity $\left(\log _{10} \mathrm{~K}_{\mathrm{sat}}\right)$ (Table5). Clay content, 1-3 cm infiltration rates and slope length were the only variables statistically significant at the $\mathrm{p}-0.05$ level. Although slope percent and hydraulic conductivity $\left(\log _{10} \mathrm{~K}_{\mathrm{sat}}\right)$ were not significant predictors at the p-0.05 level, they were still important for the binary logistic regression analysis of rill erosion occurrence model.

Table 5. Binary logistical regression analysis for predictors and the odds ratio of rill erosion occurrence.

\begin{tabular}{ll}
\hline Predictor & Odds Ratio \\
\hline Clay \% & $1.71^{*}$ \\
1cm to $3 \mathrm{~cm}$ infiltration & $1.56 *$ \\
Slope Length & $1.02 *$ \\
Slope \% & 0.90 \\
$\log _{10}\left(\mathrm{~K}_{\mathrm{sat}}\right) \mathrm{cm} / \mathrm{hr}$ & 0.47
\end{tabular}

*Sig at 0.05 levels 
All predictors are held constant as one variable increases in probability of rill erosion occuring. Illustrated in Figure 15a, the event probability of erosion and clay percent shows a positive trend. There is a 71 percent $(95 \% \mathrm{Cl}: 1.01,2.90)$ increase in odds of rilling with a one unit increase in clay percent if all other predictors are held constant. For every one unit odds of rilling there is a one unit increase in clay percent, therefore the odds of rilling increase from 1 to 190 percent, as long as all other predictors are held constant.

Infiltration at $1 \mathrm{~cm}$ to $3 \mathrm{~cm}$, exhibited a 56 percent $(95 \% \mathrm{Cl}: 1.03,2.36)$ increase in odds of rilling. The odds of rilling increase from 3 to 136 percent for every one unit increase in infiltration (Figure 15 b). Slope length showed a minimal 2 percent $(95 \%$ $\mathrm{Cl}: 1.00,1.04)$ increase in odds of rilling occuring, with a one unit increase in slope length. The odds of rilling increase from 0.01 to 0.04 percent, for every one unit increase in slope length. All other variables included in the model were not a factor in increasing the probability of rill erosion, therefore they were not statistically significant. 

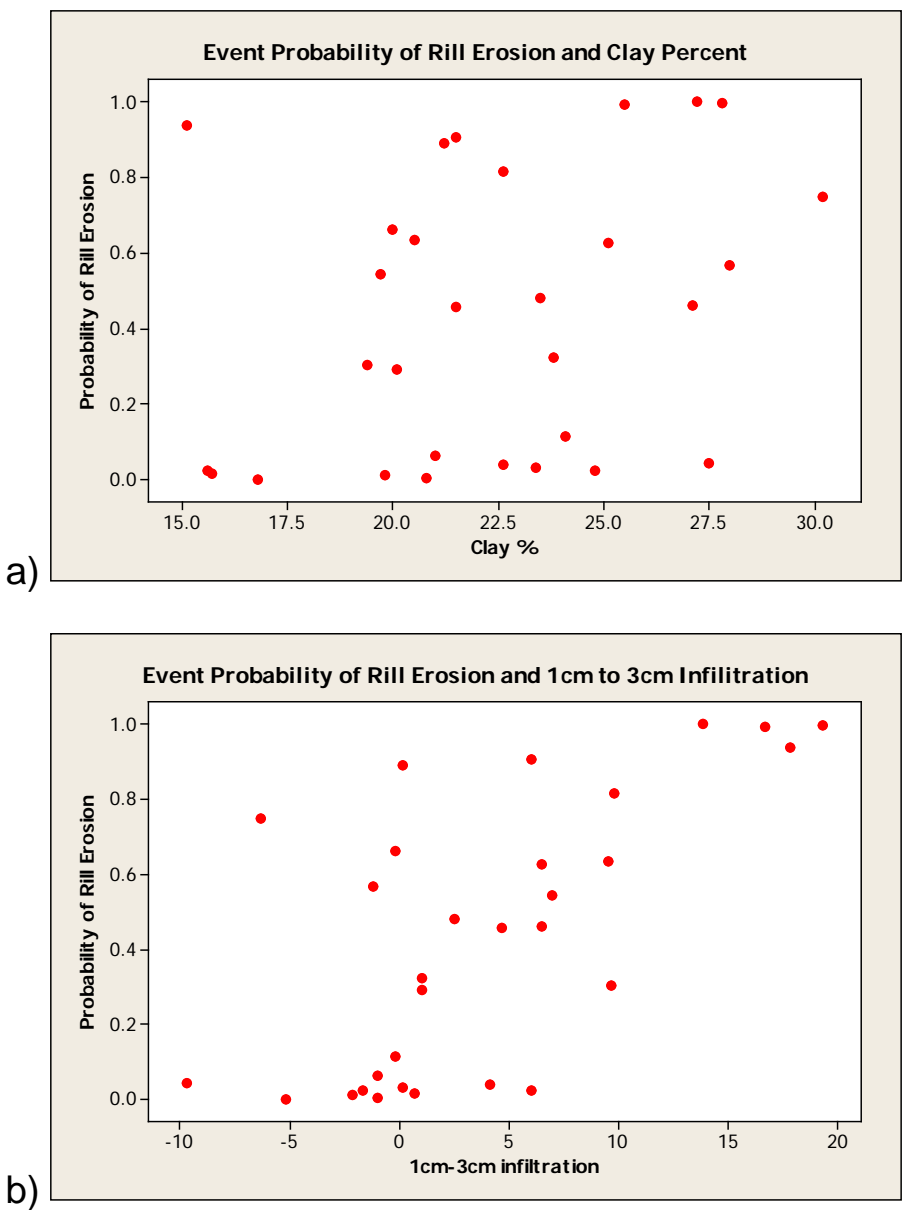

b)

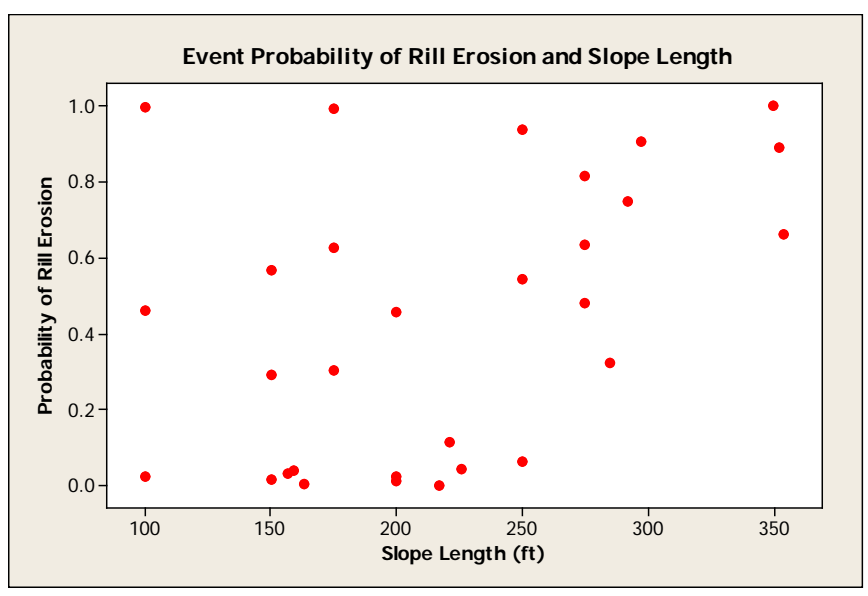

Figure 15. Error of Probability of Rill Erosion of statistically significant variables: a) clay percent, b) infiltration and c) slope length 


\section{Discussion}

Post Lockheed Fire rill erosion assessment compiled landscape and soil physical characteristic data to determine the factors associated with the extensive network of rill erosion. Statistical trails identified a combination of significant factors associated with occurrence of rill erosion. The evaluation did not identify strong relationships between the individual key variables. Soil organic matter, soil carbon, soil nitrogen, dispersion and water repellency were not statistically significant in differentiating non-rilled and rilled sites. While slope length, clay content and infiltration, were statistically significant. Saturated hydraulic conductivity $\left(\mathrm{K}_{\text {sat }}\right)$ and slope steepness were not significant, but were included in the statistical model as associated variables with the occurrence of rilling.

\section{Landscape Characteristics}

Slope length and slope steepness were both part of the statistical model. Due to the range in slope steepness being similar throughout both non-rilled and rilled locations, a trend could not be distinguished within the model to show enough difference between non-rilled and rilled locations. As a result only slope length was determined statistically significant. Both however, play a role in hillslope erosion and are accounted for in erosion prediction models, such as the RUSLE model. This is apparent on the two hillslopes where rill erosion occurred and the hillslopes steepness ranged from 45-75 percent slope with a slope length $\leq 198$ meters in length. 


\section{Soil Characteristics}

\section{Clay Content}

Clay content was statistically significant in the occurrence of rill erosion. The clay content was moderately greater at the rilled locations than non rilled locations. The overall difference in clay content from non-rill to rilled was 1.5 percent. Although it appears to be a minimal difference, it was enough to make it statistically significant when presented in the binary logistical regression with all other variables. Given that the clay percent is so minimal, it is unlikely that clay percent was the primary driving force for the occurrence of rill erosion.

Infiltration

Infiltration was statistically significant in differentiating the likelihood of rill erosion occurring on the non-rill and rill sites. Lower infiltration measurements were associated with the rilled sites at $1 \mathrm{~cm}, 3 \mathrm{~cm}$ or both. The mean infiltration at the $3 \mathrm{~cm}$ depth was lower than $1 \mathrm{~cm}$ depth for all rilled sites and non rilled transects T1-T3 sites. After a fire there is often a reduction in soil infiltration rate below the surface. Because there is a higher infiltration in the upper layer such as $1 \mathrm{~cm}$ and lower infiltration at lower depths the storage capacity of the soil can become limited. Fire can induce changes in soil properties such as grain size, porosity, cracks, or surface crusts can influence the amount of water adsorbed (Cerdà and Robichaud, 2009). The combustion of organic matter near and on the soil surface can cause changes in the soil physical properties and impacting soil infiltration as well as enhancing or causing soil water repellency (Cerdà and Robichaud, 2009). 
Non-rilled transects located on highly fractured mudstone, contained a high amount of surface fragments. The graph (Figure 13a) displays the wide range of variability $\left(0.5\right.$ to $\left.29.5 \mathrm{~mL} \mathrm{~min}^{-1}\right)$ for the infiltration in these soils. Interpretations taken at the time of sampling indicate that transect points T2 (30 and 90), were both located next to or on volatilized stumps. This suggests that the fire persisted longer around this area, most likely enhancing the soil water repellent layer. As seen in the WDPT measurements, temperatures created a heat gradient and were more repellent at lower depths. In turn, the subsurface storage capacity was reduced at $3 \mathrm{~cm}$ depth.

Hillslope 2, T8 and T9 were the only sites where the mean infiltration was not lower at the $3 \mathrm{~cm}$ depth than the $1 \mathrm{~cm}$ depth. This particular area the surface and subsurface appeared to be very unstable. This was identified by the presence of debris deposits, uprooted knobcone trees and shrubs, and presence of piping. Field observations also noted that T9 (60 and 90) sample points lacked a near surface and subsurface soil structure. These interpretations imply that the fire or post-fire conditions altered or destroyed the soil structure which resulted in a decline in porosity, pore size and roots. As a result, it reduces surface infiltration and can produce overland flow (Ubeda and Outeiro, 2009).

Rilled transect T4, T5 and T6, no trends were identified at the depth of $1 \mathrm{~cm}$, although the infiltration rates were highly variable. The subsurface, $3 \mathrm{~cm}$ depth, displayed lower infiltration rates with less variability and exhibited a consistent pattern (Figure 13b). A crusted layer and residual ash was observed throughout these sample points. The field observations and lower in infiltration may indicate that a water repellent layer persist at lower depths. This was also shown in the WDPT 
measurements, where there were more moderate and a few strong sample sites exhibiting repellency at a lower depth of $3 \mathrm{~cm}$ than at $1 \mathrm{~cm}$. A lower infiltration can also be attributed to surface sealing by ash fine soil particles and rainfall impact (Larsen et al., 2009).

Hillslope 2, T10 - T11, infiltration rate for these two transects at the 1 and $3 \mathrm{~cm}$ depths did not show any trends in the graphs. They both displayed a high variability of infiltration across the hillslope. Some of the sample points increased in infiltration from $1 \mathrm{~cm}$ to $3 \mathrm{~cm}$, while other measurements were reduced. Like T4-T6, the other rilled locations, residual ash and a crusted surface layer was observed. The fluctuation in infiltration may have been influenced by these observed characteristics creating an inconsistent pattern.

\section{Saturated Hydraulic conductivity $\left(\mathrm{K}_{\text {sat }}\right)$}

Hydraulic conductivity at 12 to $15 \mathrm{~cm}$ may not have been directly influenced by the fire, but this variable can be influenced by other soil physical properties that were altered. As displayed in the surface infiltration, permeability was also highly variable across the landscape. Saturated hydraulic conductivity was not statistically significant, but showed a positive relationship with non-rilling. All non-rilled locations demonstrated a greater overall $\left(\mathrm{K}_{\mathrm{sat}}\right)$. Suggestions for the higher $\left(\mathrm{K}_{\mathrm{sat}}\right)$ values were the large amount of rock fragments observed within the upper horizons of these non-rilled sites. The larger scale voids such as cracks, fissures, laminations or root holes allow for extremely high permeability $\left(\mathrm{K}_{\mathrm{sat}}\right)$.

The average $\left(\mathrm{K}_{\mathrm{sat}}\right)$ at rilled sites was less than non-rilled sites by approximately 
30 percent. Unlike the non-rilled, sites these locations contained fewer subsurface rock fragments. Thus less void space, and slightly higher clay content. A higher clay percent suggest that the $\left(\mathrm{K}_{\text {sat }}\right)$ will decrease because there is a larger surface area and less interconnected pore space for the water to flow. The subsurface of the non-rilled sites had larger macropores to provide preferential water paths.

Also, combining any variability of water repellency, limiting infiltration storage capacity, the soil will slowly saturate, create lateral flow and causing erosion to occur on steep bare slopes.

\section{Water Repellency}

Although water repellency was not statistically significant in the probability of rill erosion occurring, it is important to show the one year post fire measurements and point out the amount of time that has elapsed between the Lockheed Fire and this assessment. Water repellency has been a focus of post-fire research and recognized as one of the key indicators for reducing infiltration resulting in post fire runoff. Water repellency is spatially and temporally inconsistent, consequently making it harder to determine the overall extent it may have across landscape initially and overtime (Doerr and Thomas, 2000). Though no data was collected immediately after the fire in 2009, the measurements obtained in 2010 displayed mostly weak to moderate, and a few strong water repellent soils. The measurements point out that non-rilled and rilled areas display variable rates of water repellency. The variability can be a result of discontinuously spaced vegetation and organic layers that naturally contain hydrophobic compounds (DeBano, 2000), and also may be a function of decomposition 
of the waxy organic matter in the year between the Lockheed Fire and this study.

A high percentage of weak readings suggest that the repellent layer has been declining at the $1 \mathrm{~cm}$ depth, but repellency is persisting at the $3 \mathrm{~cm}$. It has been suggested that surface water repellency in chaparral ecosystems can return to pre-fire conditions over a 76 day period (Hubbert et al., 2006). Thus, seeing a large portion of the samples displaying weak to moderate, rather than strong repellency is not uncommon. It has been determined that water repellency decreases post-fire due to both physical and biological factors, predominantly surface erosion. Slopes steeper greater the 55 percent are the most vulnerable due to gravity and biologically by soil, micro-, meso-, macrofauna and root growth (Hubbert et al., 2006). 


\section{CHAPTER 5}

\section{Summary and Conclusion}

The post-fire rill erosion assessment study determined that there was no single variable controlling the occurrence of rill erosion on the two hillslopes. The network of rill erosion was caused by a combination of landscape and soil characteristics. The contributing factors investigated were clay content, infiltration, slope length and potentially associated factors were slope steepness and $\log _{10}$ saturated hydraulic conductivity ( $\left.\mathrm{K}_{\text {sat }}\right)$. Rill erosion is more likely to occur when there are higher clay percent, lower infiltration rates at 1 and $3 \mathrm{~cm}$ infiltration and slope length is greater.

Soil water repellency was not the shown to be primary cause in the post-fire surface runoff. The variability and patchiness of the water repellency layer across the transects suggest that this layer may have been returning to its pre-fire state at the time of sampling. The water repellent layer declines when the hydrophobic substance dissolves and the soil is wettable again, possibly due to seasonal moisture, biological activity, revegetation, or soil moisture.

The Lockheed Fire burned a large portion of Little Creek subwatershed creating a mosaic patter of various burn severities. The severities were classified from moderate to high, indicating that there were various degrees of water repellent layers across the landscape. On these two chaparral hillslopes, 90 percent or more of the vegetation was consumed by the fire. This left behind unprotected bare soils on long, steep to very steep hillslopes. During the January and February rain event, the rainfall exceeded the infiltration capacity. At this time water was able to infiltrate through the 1 
$\mathrm{cm}$ depth however infiltration at $3 \mathrm{~cm}$ depth was obstructed lower the amount water infiltration at $3 \mathrm{~cm}$ and the storage between 1 and $3 \mathrm{~cm}$. The infiltration pattern on these steep and lengthy slopes along with the, soil texture and depth, allow for more velocity as soil particles travel down the hillslope. Eventually, this process cuts deeper into the soil creating an increase in sedimentation, as seen on the backslopes of Hillslope 1 and 2. As a result a large quantity of sediment was lost from the two hillslopes. By knowing what factors contributed to the network of rill erosion from this hillslope, the entire watershed can be better understood for both pre-fire and post-fire.

This study has provided an overall broad perspective of the site and soil conditions to help determine what characteristics were associated with rill erosion. To improve this study design fewer variables would be selected and smaller area would be examined. Possible designing box plots on the landscape with more sample points within a smaller area to capture the variability of the infiltration and water repellency may have given more insight to what was occurring.

Although the assessment was a large scale project the data that was collected from this can be useful to Cal Poly's, Swanton Pacific Ranch managers and students. It can be used to understand what factors did and did not contribute to the occurrence of rill erosion. The data that was collected leading to the results of this study can be the basis for other projects to further understand the erosion process of these two unstable hillslope. This will allow the ranch and other organizations to plan for future management of the overall watershed and critical habitat in Scotts Creek. 


\section{REFERENCES}

Bowman, R.H., and D.C. Estrada 1980. Soil Survey of Santa Cruz County, California, USDA Soil Conservation Service

Brabb, E.E., 1997. Geologic Map of Santa Cruz County, California: a digital database: U.S. Geological Survey, Open-File Report OF-97-489, scale 1:62500.

Cal Fire. 2009, (Sept. 30). Lockheed fire post risk assessment. San Mateo- Santa Cruz Unit, California Department of Forestry and Fire Protection.

California Academy of Sciences. 2008. Hotspot: California on the edge. http://www.calacademy.org/exhibits/california_hotspot/overview.htm.

Cerdà, A., and P.R. Robichaud, 2009. Fire Effects on Soil Infiltration. Chapter 3 in: Cerdà, A., and P.R. Robichaud, eds. Fire Effects on Soils and Restoration Strategies. 2009. Enfield, NH: Science Publishers. 81-104

DeBano, L.F. 2000. The role of fire and soil heating on water repellency in Wildland environments: A review. J. Hydrol. 231-232: 195-206.

DeBano, L.F. 1981. Water repellent soils: a state- of - the -art. USDA Forest Service General Technical Report PS W-46

Decagon Devices Inc.2007. Infiltrometer Product Guide, http://www.decagon.com/instruments/infilt.html [2010, July]

Doerr, S.H., R.A. Shakesby, L.W. Dekker, and C.J. Ritsema. 2006. Occurence, prediction and hydrological effects of water repellency amongst major soil and land use types in a humid temperate climate. Eur. J. Soil Sci., 57; 741-754

Doerr, S.H. and A.D. Thomas, 2000. The role of soil moisture in controlling water repellency; new evidence from forest soils in Protugal. J. Hydrol. 231 (232), 134-147.

Gee, G. W. and D. Orr. 2002. Particle size analysis, p. 255-293. In Dane J.H. and G. C. Topp (editors), Methods of Soil Analysis Part 4 Physical Methods. Soil Science Society of America, Inc., Madison, WI.

Hubbert, K.R., H.K. Preisler, P.M. Wohlgemuth, R.C. Graham, and M.G. Naroga. 2006. Prescribed burning effects on soil physical properties and soil water repellency in a steep chaparral watershed, southern California, USA Geoderma 130: 284- 298

Huffman, E.L., L.H. MacDonald, and J.D., Stendnick, 2001. Strength and persistence of fire- induced soil hydrophobicity under ponderosa and lodgepole pine, Colorado Front Range. Hydrol Process. (15): 2877-2802 
Larsen, I.J., L.H. MacDonald, E. Brown, D. Rough, M.J. Welsh, J.H. Pietraszek, Z. Libohova, J.D. Benavides-Solorio, and K.Schaffrath, 2009. Cause of Post-Fire Runoff and Erosion: Water Repellency, Cover, or Soil Sealing?. Soil Sci. Soc. Am. J. 73:11393-1407

Lloret, F. and P.H. Zedler, 2009. The Effects of Forest Fire on Vegetation, Chapter 9 in: Cerdà, A. and P.R. Robichaud, eds. Fire Effects on Soils and Restoration Strategies. 2009. Enfield, NH: Science Publishers.

Moody, J.A., D.A. Kinner, and X. Ubeda. 2009. Linking hydraulic properties of fireaffected soils to infiltration and water repellency. J. Hydrol. 379:291-303.

Moody, J.A. and A. A. Martin, 2001, Initial hydrological and geological Response Following a Wildfire in Colorado Front Range. Earth Surface Processes and Landforms 25:1049-1070

National Marine Fisheries Service. 2010. Public Draft Recovery Plan for Central California Coast Coho salmon (Oncorhynchus kisutch) Evolutionarily Significant Unit. In Chapter 10, National Marine Fisheries Service, Southwest Region, Santa Rosa, California.

NRES (Natural Resource Environmental Science) Department, Cal Poly State University, GIS Database. 2011

NRCS Soil Survey Geographic (SSURGO) Database, http://datagateway.nrcs.usda.gov/

Neary, D.G., K.C. Ryan, L.F. DeBano, eds. 2005. Wild fire in ecosystems: effects of fire on soils and water. Gen. Tech. Rep. RMRS-GT-42-vol.4.Ogden, UT: U.S. Department of Agriculture, Forest Service, Rocky Mountain Research Station.

Pierson, F.B., P.R. Robichaud, C.A. Moffet, K.E. Spaeth, S.P. Hardegree, P.E. Clark, and C.J.Williams. 2008a. Fire effects on rangeland hydrology and erosion in a steep sagebrush-dominated landscape. Hydrol Process. 22:2916-2929.

Pierson, F.B., P.R. Robichaud, C.A. Moffet, K.E. Spaeth, C.J. Williams, S.P. Hardegree, and P.E. Clark. 2008b. Soil water repellency and infiltration in coarsetextured soils of burned and unburned sagebrush ecosystems. Catena 74:98-108.

PRISM Climate Group, Oregon State University, http://prism.oregonstate.edu, created 12 March 2011.

Robichaud, P.R., S.A. Lewis, and L.E. Ashmun. 2008. New procedure for sampling infiltration to assess post-fire soil water repellency. USDA Forest Service Research Note RMRS-RN-33.

Schoeneberger, P.J., D.A. Wysocki, D.C. Benham, and W.D. Broderson (eds.). 2002. 
Field Book for Describing and Sampling Soils. Version 2.0. Nat. Res. Cons. Serv., Nat. Soil Survey Center. Lincoln, NE.

Scott, D.F., M.P. Curran, P.R. Robichaud, and J.W. Wagenbrenner.2009, Soil Erosion after Forest Fire. Chapter 6 in: Cerdà, A and P.R. Robichaud, eds. Fire Effects on Soils and Restoration Strategies. 2009. Enfield, NH: Science Publishers.

Scotts Creek Watershed Council, 2000. Roads and Landslides Sediment Source Investigation and Sediment Reduction Plan for the Scotts Creek Watershed, Santa Cruz County, California. Prepared for the Scotts Creek Watershed. Unpublished.

Sherard, J.L., L.P. Dunnigan, and R.S. Decker. 1976. Identification and nature of dispersive soils. J. of the Geotech. Division, A.S.C.E. 102: 287-301.

Soil Survey Staff. 2006. Keys to Soil Taxonomy. Tenth Ed. USDA Nat. Res. Cons. Serv.

Swanton Pacific Ranch, 2010, Little Creek Rainfall data. Unpublished raw data.

Swanton Pacific Ranch, Cal Poly State University, http:spranch.org/about.ldml

Ubeda X, and L.R. Outeiro. 2009, Physical and Chemical Effects of Fire on Soil. Chapter 4 in: Cerdà, A.; Robichaud, P.R., eds. Fire Effects on Soils and Restoration Strategies. 2009. Enfield, NH: Science Publishers.

Volk, G.M. 1937. Method of determination of the degree of dispersion of the clay fraction of soils. Soil Sci. Soc. Am. Proceedings 11: 561-565. 


\section{APPENDICES}


Appendix A. Vegetation List

Table 6. Plant Identification on research hillslopes post-fire. Plant ID by Botanist Jim West

\begin{tabular}{|c|c|c|}
\hline $\begin{array}{l}\text { Knobcone Pine/ } \\
\text { Chaparral and Chaparral } \\
\text { Mix }\end{array}$ & Scientific name & Common name \\
\hline \multicolumn{3}{|l|}{ Trees } \\
\hline & Pinus attenuate & Knobcone Pine \\
\hline & Arbutus menziesii & Madrone \\
\hline & Heteromeles arbutifolia & Toyon \\
\hline Shrubs and Forbes & Baccharis pilularis & Coyote brush \\
\hline $\begin{array}{l}\text { after fire resprouter and } \\
\text { seed dispersal }\end{array}$ & Adenostoma fasciculatum & Chamise \\
\hline \multirow[t]{16}{*}{ after fire resprouter } & Arctostaphylos & Manzanita \\
\hline & Ceanothus thyrsiflorus & Bluebonnett \\
\hline & Eriodictyon californicum & Yerba Santa \\
\hline & $\begin{array}{l}\text { Sambucous nigra subsp, } \\
\text { canadencis }\end{array}$ & Blue Elderberry \\
\hline & Quercus ilicifolia & Scrub oak \\
\hline & Pseudognaphalium & Pink Everlast \\
\hline & $\underline{\text { ramosissimum }}$ & \\
\hline & Emmenanthe penduliflora & Whispering Bells \\
\hline & $\begin{array}{l}\text { Lotus scoparius } \\
\text { Lotus micranthus }\end{array}$ & Deerweed \\
\hline & Scrophularia californica & Figwart \\
\hline & Toxicodendron diversilobum & Poison Oak \\
\hline & $\begin{array}{l}\text { Calystegia purpurata subsp. } \\
\text { Purpurata }\end{array}$ & Morning Glory \\
\hline & $\begin{array}{l}\text { Lupinus arboreus complex } \\
\text { aff., L. propinquus }\end{array}$ & Lupin \\
\hline & Conyza canadensis & $\begin{array}{l}\text { Yarrow canadensis, Yarrow } \\
\text { (Achillea millefolium }\end{array}$ \\
\hline & Trifolium microseptum & Clover \\
\hline & Mimulus aurantiacus & Sticky Monkey- Flower \\
\hline \multirow{3}{*}{$\begin{array}{l}\text { Grass: } \\
\text { blooms in disturbed } \\
\text { areas } \\
\text { Non-native }\end{array}$} & & \\
\hline & Calamagrostis rubescens & Pinegrass \\
\hline & $\begin{array}{l}\text { Gnaphalium sp. } \\
\text { Luteoalbum, } \\
\text { Cirsium vulgare (Savi) Ten. }\end{array}$ & Bull thistle \\
\hline
\end{tabular}


Appendix B. Soil Pedon Descriptions

\section{Abbreviations}

\section{Boundary}

Distinctness (Dist): A=Abrupt, $C=$ Clear, $G=$ Gradual, $D=$ Diffuse

Topography (Topo): $S=S m o o t h, W=W a v y, ~ I=I r r e g u l a r$

\section{Rock Fragment Modifiers}

RF Mod: GR=Gravelly, CGR=Coarse Gravelly, CB=Cobbly, VCB =Very Cobbly, ST=Stony

\section{Pores}

Shape: IR= Interstitial, VE= Vesicular

\section{Structure}

Type: GR=Gravely, ABK=Angular Blocky, SBK= Subangular Blocky

Size: VF=Very Fine, $F=$ Fine, $M=$ Medium, $C O=$ Course, $V C=$ Very Coarse

\section{Consistence}

Rupture Resistance,

Dry: $\mathrm{SO}=$ Soft, $\mathrm{SH}=$ Slightly Hard

Moist (Mst.): VF= Very Friable, FR=Friable

Plasticity (SI): $\mathrm{PO}=$ Non-Plastic, $\mathrm{SP}=$ Slightly Plastic, $\mathrm{MP}=$ Moderately Plastic

Stickiness (ST): SO= Non-Sticky, SS= Slightly Sticky, MS- Moderately Sticky, VS= Very Sticky

\section{Roots}

Amount: 1= Very Few - Moderately Few, 2= Common, 3= Many

Size: VF= Very Fine, $\mathrm{F}=$ Fine, $\mathrm{M}=$ Medium, $\mathrm{C}=$ Coarse 
Appendix B. Soil Pedon Description 1

Pedon: Site 1

Latitude: N 37.0764 Longitude: W 122.20623

Vegetation: Knobcone pine overstory, Mix Chaparral understory

Parent Material: Residuum, weathered from mudstone

Landform: Hillslope

Slope Steepness: $65 \%$

Aspect: S $150 \mathrm{E}$

Elevation: $1268 \mathrm{ft}$

Site Position: Summit/ Shoulder

loamy-skeletal, mixed, superactive, thermic shallow Lithic Haploxerepts

\begin{tabular}{|c|c|c|c|c|c|c|c|c|c|c|c|c|c|c|c|}
\hline Horizon & Bounda & ry & & Color & & $\begin{array}{l}\text { Rock } \\
\text { Fragm }\end{array}$ & & Pores & Struc & & Consis & ence & & Roots & $\mathrm{pH}$ \\
\hline & $\begin{array}{l}\text { Depth } \\
(\mathrm{cm})\end{array}$ & Dist & Topo & Dry & Moist & $\begin{array}{l}\text { RF } \\
\text { Mod }\end{array}$ & $\%$ & Shape & Type & $\begin{array}{l}\text { Siz } \\
\mathrm{e}\end{array}$ & $\begin{array}{l}\text { Dryl } \\
\text { Mst. }\end{array}$ & $\mathrm{Pl} / \mathrm{St}$ & Amt & Size & \\
\hline$A$ & $0-9$ & $\mathrm{C}$ & $\mathrm{D}$ & $\begin{array}{l}\text { 10YR } \\
6 / 2\end{array}$ & $\begin{array}{l}\text { 10YR } \\
3 / 2\end{array}$ & CGR & $x$ & IR & GR & VF & S/ VF & $\begin{array}{l}\text { SP/S } \\
\text { S }\end{array}$ & $\begin{array}{l}2 \\
2\end{array}$ & $\begin{array}{l}\text { VF } \\
F\end{array}$ & 5 \\
\hline$A C$ & $9-22$ & $\mathrm{C}$ & 1 & $\begin{array}{l}10 Y R \\
6 / 2\end{array}$ & $\begin{array}{l}\text { 10YR } \\
3 / 2\end{array}$ & CB & $x$ & IR & ABK & VF & S/ FR & P/ SS & $\begin{array}{l}2 \\
2\end{array}$ & $\begin{array}{l}\text { VF } \\
F\end{array}$ & 5 \\
\hline $\mathrm{Cr}$ & $22-60$ & $\mathrm{C}$ & I & $\begin{array}{l}10 Y R \\
7 / 3\end{array}$ & $\begin{array}{l}10 Y R \\
6 / 6\end{array}$ & VCB & $x$ & IR & ABK & VF & S/ FR & P/ SS & 1 & $F$ & 5.5 \\
\hline
\end{tabular}

Comments:

- $\quad>50 \%$ Rock Fragment Surface Coverage

- Percent Rock Fragment was not recorded for this soil pedon. From memory it was very it was very high or comparable to pedon 4, See pedon photo for visual on page 58.

- No data for rock fragment percent 
Table 7. Pedon 1, Lab Results

\begin{tabular}{lllllllllll}
\hline Pedon & Horizon & $\begin{array}{l}\text { Depth } \\
(\mathrm{cm})\end{array}$ & Texture & $\begin{array}{l}\text { Sand } \\
(\%)\end{array}$ & $\begin{array}{l}\text { Clay } \\
(\%)\end{array}$ & $\begin{array}{l}\text { Dispersion } \\
\text { ratio }\end{array}$ & $\begin{array}{l}\text { Organic } \\
\text { Matter }(\%)\end{array}$ & $\begin{array}{l}\text { C/N } \\
\text { ratio }\end{array}$ & $\begin{array}{l}\text { Carbon } \\
(\%)\end{array}$ & $\begin{array}{l}\text { Nitrogen } \\
(\%)\end{array}$ \\
\hline 1 & A & $0-9$ & Loam & 33 & 25 & 0.07 & 12.2 & 17.2 & 6.1 & 0.4 \\
& AC & $9-22$ & Loam & 36 & 21 & 0.14 & 8.2 & 16.8 & 4.1 & 0.2 \\
& Cr & $22-60$ & Loam & 30 & 23 & 0.25 & 7.9 & 16.2 & 3.9 & 0.2 \\
\hline
\end{tabular}

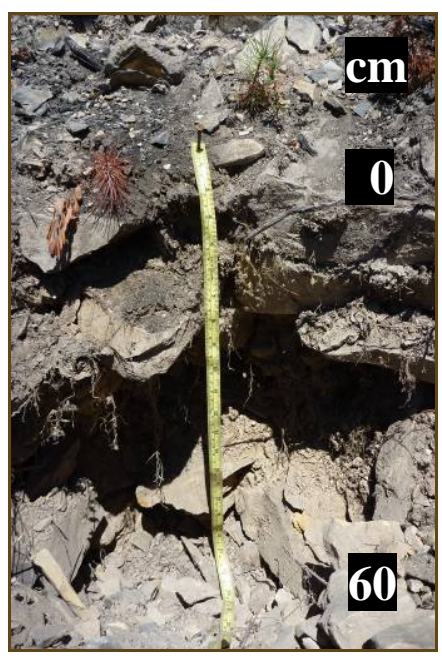

Figure 16. Pedon 1, Profile picture 
Appendix B. Soil Pedon Description 2

Pedon: Site 2

Latitude: N 37.0756

Longitude: W 122.2057

Vegetation: Mix Chaparral

Parent Material: Colluvium, Mudstone/Sandstone

Landform: Hillslope

Slope Steepness: $65 \%$

Aspect: S $150 \mathrm{E}$

Elevation: $1005 \mathrm{ft}$

Site Position: Backslope

loamy, mixed super active, thermic Typic Haploxerolls

\begin{tabular}{|c|c|c|c|c|c|c|c|c|c|c|c|c|c|c|c|}
\hline \multirow[t]{2}{*}{ Horizon } & \multicolumn{3}{|c|}{ Boundary } & \multicolumn{2}{|l|}{ Color } & \multicolumn{2}{|c|}{$\begin{array}{l}\text { Rock } \\
\text { Fragment }\end{array}$} & \multirow{2}{*}{$\begin{array}{l}\text { Pores } \\
\text { Shape }\end{array}$} & \multicolumn{2}{|c|}{ Structure } & \multicolumn{2}{|c|}{ Consistence } & \multicolumn{2}{|l|}{ Roots } & \multirow[t]{2}{*}{$\mathrm{pH}$} \\
\hline & $\begin{array}{l}\text { Depth } \\
(\mathrm{cm})\end{array}$ & Dist. & Topo. & Dry & Moist & $\begin{array}{l}\text { RF } \\
\text { Mod }\end{array}$ & $\%$ & & Type & Size & $\begin{array}{l}\text { Dryl } \\
\text { Mst. }\end{array}$ & $\mathrm{Pl} / \mathrm{St}$ & Qty. & Size & \\
\hline $\mathrm{A} 1$ & $0-17$ & $\mathrm{C}$ & $\mathrm{S}$ & $\begin{array}{l}10 Y R \\
3 / 2\end{array}$ & $\begin{array}{l}\text { 10YR } \\
2 / 1\end{array}$ & GR & 17 & IR & $\begin{array}{l}\text { GR- } \\
\text { ABK }\end{array}$ & $\mathrm{F}$ & $\begin{array}{l}\text { S- } \\
\text { VFR }\end{array}$ & $\begin{array}{l}\text { SS/ } \\
\text { SP }\end{array}$ & $\begin{array}{l}3 \\
3 \\
2\end{array}$ & $\begin{array}{l}\text { VF } \\
F \\
M\end{array}$ & 5.5 \\
\hline A2 & $17-40$ & C & $\mathrm{S}$ & $\begin{array}{l}10 Y R \\
4 / 2\end{array}$ & $\begin{array}{l}10 Y R \\
2 / 1\end{array}$ & $\begin{array}{l}\text { GR- } \\
\text { CB }\end{array}$ & $\begin{array}{l}10- \\
3\end{array}$ & IR & $\begin{array}{l}\text { GR- } \\
\text { ABK }\end{array}$ & $\mathrm{F}$ & $\begin{array}{l}\text { S/ } \\
\text { VFR }\end{array}$ & $\begin{array}{l}\text { SS/ } \\
\text { SP }\end{array}$ & $\begin{array}{l}1 \\
3\end{array}$ & $\begin{array}{l}\mathrm{C} \\
\mathrm{C}\end{array}$ & 6 \\
\hline$A / C$ & $40-75$ & A & $\mathrm{S}$ & $\begin{array}{l}\text { 10YR } \\
4 / 2\end{array}$ & $\begin{array}{l}10 Y R \\
3 / 1\end{array}$ & CB & 15 & IR & ABK & $F$ & $\begin{array}{l}\text { S/ } \\
\text { VFR }\end{array}$ & $\begin{array}{l}\text { SS/ } \\
\text { SP }\end{array}$ & $\begin{array}{l}1 \\
3\end{array}$ & $\begin{array}{l}\mathrm{C} \\
\mathrm{C}\end{array}$ & 6 \\
\hline C & $75-92$ & A & W & $\begin{array}{l}10 Y R \\
3 / 1\end{array}$ & $\begin{array}{l}\text { 10YR } \\
4 / 2\end{array}$ & CB & 50 & & SBK & VF & $\begin{array}{l}\text { S/ } \\
\text { VFR }\end{array}$ & $\begin{array}{l}\text { SS/ } \\
\text { SP }\end{array}$ & $\begin{array}{l}1 \\
3\end{array}$ & $\begin{array}{l}\mathrm{C} \\
\mathrm{C}\end{array}$ & 5.5 \\
\hline
\end{tabular}


Table 8. Pedon 2, Lab Results

\begin{tabular}{lllllllllll}
\hline Pedon & Horizon & $\begin{array}{l}\text { Depth } \\
(\mathrm{cm})\end{array}$ & Texture & $\begin{array}{l}\text { Sand } \\
(\%)\end{array}$ & $\begin{array}{l}\text { Clay } \\
(\%)\end{array}$ & $\begin{array}{l}\text { Dispersion } \\
\text { ratio }\end{array}$ & $\begin{array}{l}\text { Organic } \\
\text { Matter (\%) }\end{array}$ & $\begin{array}{l}\text { C/N } \\
\text { ratio }\end{array}$ & $\begin{array}{l}\text { Carbon } \\
(\%)\end{array}$ & $\begin{array}{l}\text { Nitrogen } \\
(\%)\end{array}$ \\
\hline 2 & A1 & $0-17$ & Sandy & 55 & 15 & 0.17 & 6.64 & 17.86 & 3.32 & 0.186 \\
& & & Loam & & & & & & & \\
& A2 & $17-40$ & Loam & 46 & 23 & 0.14 & 5.29 & 14.75 & 2.65 & 0.179 \\
& AC & $40-75$ & Loam & 49 & 19 & 0.17 & 2.01 & 11.01 & 1.01 & 0.091 \\
& C & $75-92$ & Loam & 51 & 16 & 0.27 & 1.04 & 11.02 & .699 & 0.063 \\
\hline
\end{tabular}

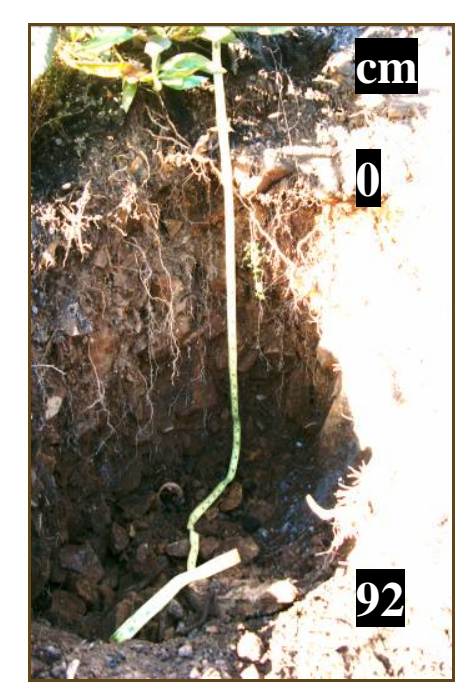

Figure 17. Pedon 2, Profile picture 
Appendix B. Soil Pedon Description 3

Pedon: Site 3

Latitude: N 37.07293

Vegetation: Mixed Chaparral

Longitude: W 122.20847

Parent Material: Colluvium

Landform: Hillslope

Slope Steepness: $55 \%$

Aspect: 144

Elevation: $769 \mathrm{ft}$

Site Position: Backslope

loamy, mixed superactive, thermic Typic Argixerolls

\begin{tabular}{|c|c|c|c|c|c|c|c|c|c|c|c|c|c|c|c|}
\hline \multirow[t]{2}{*}{ Horizon } & \multicolumn{3}{|c|}{ Boundary } & \multicolumn{2}{|l|}{ Color } & \multicolumn{2}{|c|}{$\begin{array}{l}\text { Rock } \\
\text { Fragment }\end{array}$} & \multirow{2}{*}{$\begin{array}{l}\text { Pores } \\
\text { Shape }\end{array}$} & \multicolumn{2}{|c|}{ Structure } & \multicolumn{2}{|c|}{ Consistence } & \multicolumn{2}{|c|}{ Roots } & \multirow[t]{2}{*}{$\mathrm{pH}$} \\
\hline & $\begin{array}{l}\text { Depth } \\
\text { (cm) }\end{array}$ & Dist. & Topo & Dry & Moist & $\begin{array}{l}\text { RF } \\
\text { Mod }\end{array}$ & $\%$ & & $\begin{array}{l}\text { Typ } \\
\text { e }\end{array}$ & Size & $\begin{array}{l}\text { Dryl } \\
\text { Mst. }\end{array}$ & $\mathrm{Pl} / \mathrm{St}$ & Amt. & Size & \\
\hline A & $0-15$ & C & W & $\begin{array}{l}\text { 10YR } \\
5 / 2\end{array}$ & $\begin{array}{l}10 Y R \\
2 / 2\end{array}$ & $\begin{array}{l}\text { GR } \\
\text { /CGR }\end{array}$ & 30 & VE & GR & F/M & $\begin{array}{l}\mathrm{SH} / \\
\text { VF }\end{array}$ & $\begin{array}{l}\text { MPI } \\
\text { SS }\end{array}$ & $\begin{array}{l}3 \\
3\end{array}$ & $\begin{array}{l}\text { VF } \\
F\end{array}$ & 5.5 \\
\hline $\mathrm{Bt}$ & $15-37$ & G & S & $\begin{array}{l}\text { 10YR } \\
5 / 3\end{array}$ & $\begin{array}{l}10 Y R \\
3 / 3\end{array}$ & CGR & 28 & VE & SBK & F/M & $\begin{array}{l}\mathrm{SH} / \\
\mathrm{FR}\end{array}$ & MP/MS & $\begin{array}{l}2 \\
2\end{array}$ & $\begin{array}{l}\mathrm{F} \\
\mathrm{M}\end{array}$ & 6 \\
\hline C & $37-76$ & G & S & $\begin{array}{l}\text { 10YR } \\
5 / 3\end{array}$ & $\begin{array}{l}10 Y R \\
4 / 4\end{array}$ & CGR & 20 & VE & SBK & F/M & $\begin{array}{l}\mathrm{SH} / \\
\mathrm{FR}\end{array}$ & MP/MS & 1 & $F$ & 6 \\
\hline
\end{tabular}

Comments:

- Clay Mottles and krotavinas were found in both the Bt and C Horizons

- Approximately $30 \%$ surface fragments; 
Table 9. Pedon 3, Lab Results

\begin{tabular}{lllllllllll}
\hline Pedon & Horizon & $\begin{array}{l}\text { Depth } \\
(\mathrm{cm})\end{array}$ & Texture & $\begin{array}{l}\text { Sand } \\
(\%)\end{array}$ & $\begin{array}{l}\text { Clay } \\
(\%)\end{array}$ & $\begin{array}{l}\text { Dispersion } \\
\text { ratio }\end{array}$ & $\begin{array}{l}\text { Organic } \\
\text { Matter (\%) }\end{array}$ & $\begin{array}{l}\text { C/N } \\
\text { ratio }\end{array}$ & $\begin{array}{l}\text { Carbon } \\
(\%)\end{array}$ & $\begin{array}{l}\text { Nitrogen } \\
(\%)\end{array}$ \\
\hline 3 & $\mathrm{~A}$ & $0-15$ & Loam & 41 & 12 & 0.12 & 5.86 & 14.7 & 2.93 & 0.20 \\
& $\mathrm{Bt}$ & $15-37$ & Loam & 39 & 13 & 0.47 & 1.0 & 8.69 & 0.50 & 0.06 \\
& $\mathrm{C}$ & $37-76$ & Loam & 40 & 15 & 0.44 & 0.56 & 7.44 & 0.28 & 0.04 \\
\hline
\end{tabular}

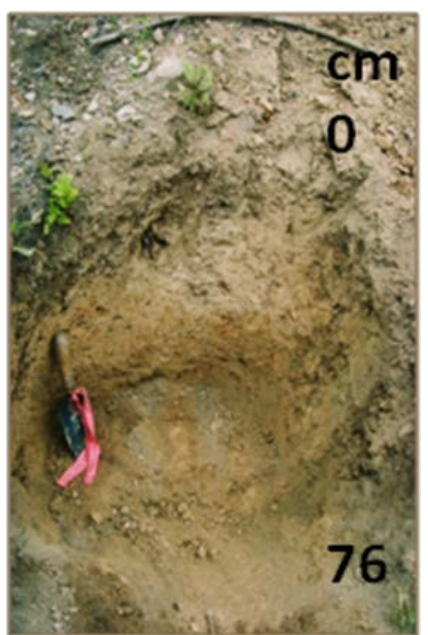

Figure 18. Pedon 3, Profile picture 
Appendix B. Soil Pedon Description 4

Pedon: Site 4

Latitude: N 38.07334

Vegetation: Mix Chaparral

Parent Material: Colluvium

Landform: Hillslope

Slope Steepness: $52 \%$

Aspect: $179 \mathrm{~S}$
Longitude: W 122.20838

Elevation: $847 \mathrm{ft}$

Site Position: Shoulder/Backslope

loamy-skeletal mixed superactive thermic shallow lithic Haploxerepts

\begin{tabular}{|c|c|c|c|c|c|c|c|c|c|c|c|c|c|c|c|}
\hline \multirow[t]{2}{*}{ Horizon } & \multicolumn{3}{|c|}{ Boundary } & \multicolumn{2}{|l|}{ Color } & \multicolumn{2}{|c|}{$\begin{array}{l}\text { Rock } \\
\text { Fragment }\end{array}$} & \multirow{2}{*}{$\begin{array}{l}\text { Pores } \\
\text { Shape }\end{array}$} & \multicolumn{2}{|c|}{ Structure } & \multicolumn{2}{|c|}{ Consistence } & \multicolumn{2}{|c|}{ Roots } & \multirow[t]{2}{*}{$\mathrm{pH}$} \\
\hline & $\begin{array}{l}\text { Depth } \\
(\mathrm{cm})\end{array}$ & Dist. & Topo & Dry & Moist & $\begin{array}{l}\text { RF } \\
\text { Mod }\end{array}$ & $\%$ & & Type & Size & $\begin{array}{l}\text { Dryl } \\
\text { Mst. }\end{array}$ & $\mathrm{Pl} / \mathrm{St}$ & Amt & Size & \\
\hline$A$ & $0-13$ & $\mathrm{C}$ & $\mathrm{S}$ & $\begin{array}{l}\text { 10YR } \\
4 / 2\end{array}$ & $\begin{array}{l}\text { 10YR } \\
2 / 1\end{array}$ & CGR & 45 & IR & GR & FR & $\begin{array}{l}\mathrm{SO} / \\
\mathrm{VF}\end{array}$ & $\begin{array}{l}\text { SPI } \\
\text { SS }\end{array}$ & $\begin{array}{l}3 \\
3\end{array}$ & $\begin{array}{l}\mathrm{F} \\
\mathrm{C}\end{array}$ & 5.5 \\
\hline$A C$ & $13-28$ & C & W & $\begin{array}{l}10 Y R \\
5 / 3\end{array}$ & $\begin{array}{l}10 Y R \\
3 / 3\end{array}$ & CGR & & IR & $\begin{array}{l}A B \\
K\end{array}$ & $M$ & $\begin{array}{l}\mathrm{SO} / \\
\mathrm{FR}\end{array}$ & $\begin{array}{l}\text { SPI } \\
\text { SS }\end{array}$ & $\begin{array}{l}3 \\
3\end{array}$ & $\begin{array}{l}\mathrm{F} \\
\mathrm{C}\end{array}$ & 6 \\
\hline
\end{tabular}


Table 10. Pedon 4, Lab Results

\begin{tabular}{lllllllllll}
\hline Pedon & Horizon & $\begin{array}{l}\text { Depth } \\
(\mathrm{cm})\end{array}$ & Texture & $\begin{array}{l}\text { Sand } \\
(\%)\end{array}$ & $\begin{array}{l}\text { Clay } \\
(\%)\end{array}$ & $\begin{array}{l}\text { Dispersion } \\
\text { ratio }\end{array}$ & $\begin{array}{l}\text { Organic } \\
\text { Matter (\%) }\end{array}$ & $\begin{array}{l}\text { C/N } \\
\text { ratio }\end{array}$ & $\begin{array}{l}\text { Carbon } \\
(\%)\end{array}$ & $\begin{array}{l}\text { Nitrogen } \\
(\%)\end{array}$ \\
\hline 4 & A & $0-13$ & Loam & 46 & 17 & 0.22 & 9.86 & 21.01 & 4.93 & 0.24 \\
& AC & $13-28$ & Loam & 47 & 16 & 0.29 & 3.07 & 15.36 & 1.54 & 0.10 \\
& C & $28-76$ & $\begin{array}{l}\text { Sandy } \\
\text { Loam }\end{array}$ & 73 & 12 & 0.44 & 1.62 & 12.43 & 0.81 & 0.07 \\
\hline
\end{tabular}

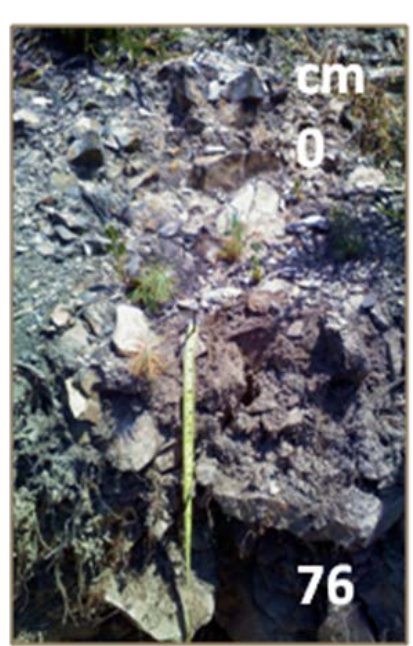

Figure 19. Pedon 4, Profile Picture 
Appendix C. Soil Pedon 1, Hillslope 1: Shoulder, Transects 1-3

a)

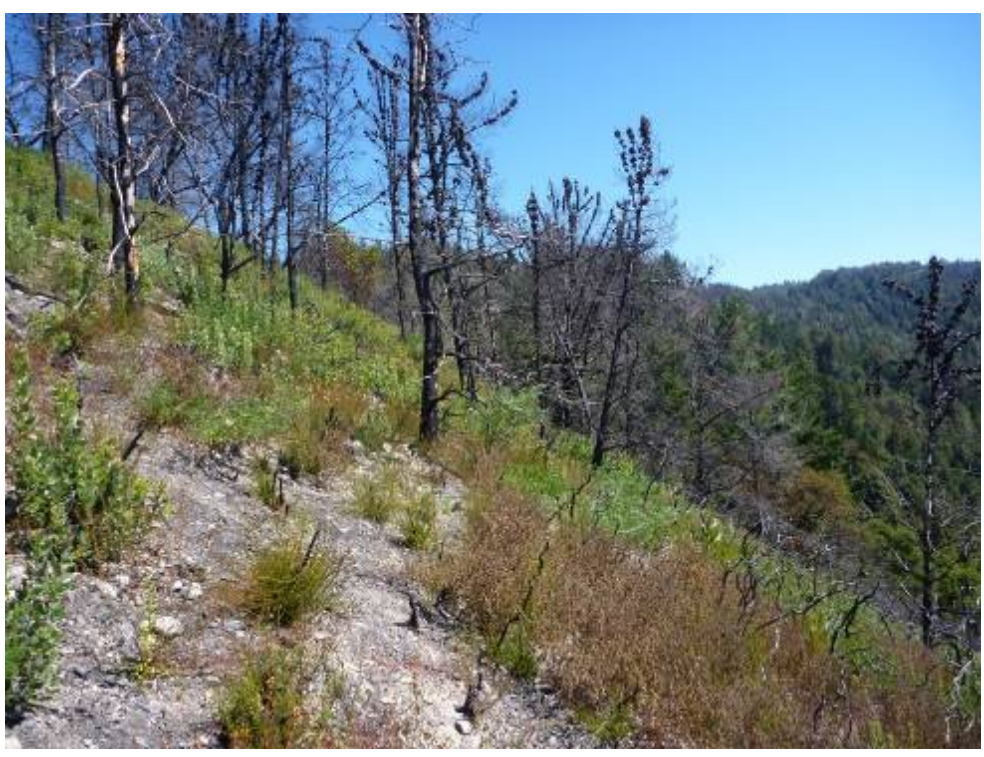

b)

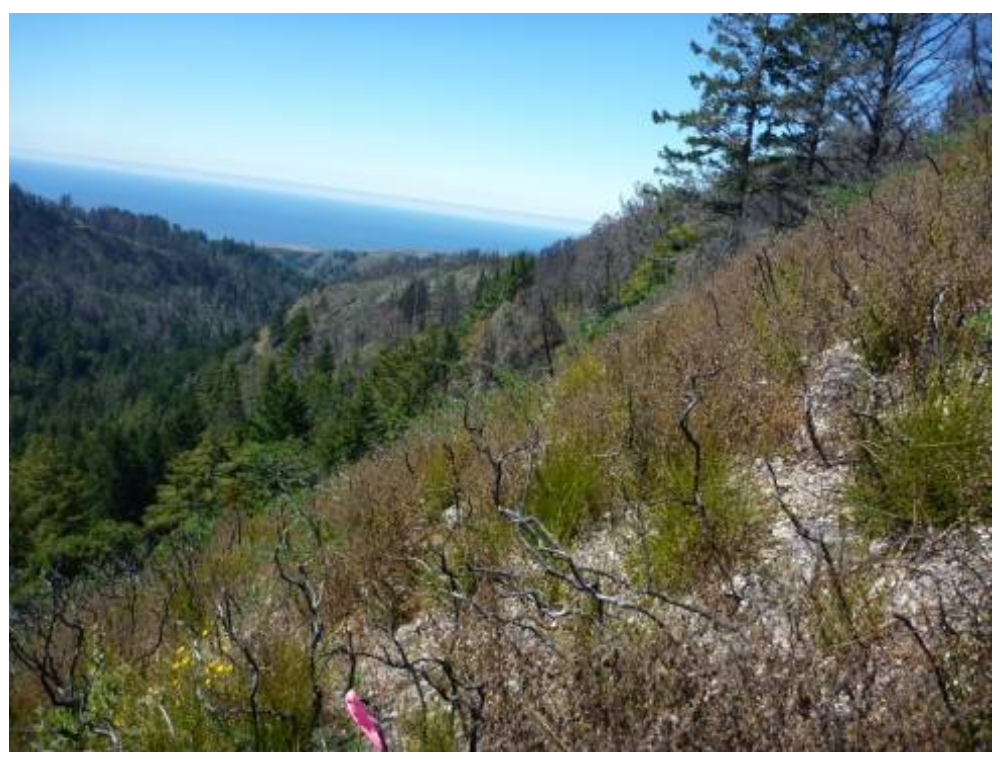

Figure 20. a)Taken looking east toward the beginning of transect 2. b) Photo taken at the start of transect 3 , looking west towards the end of the transect.

These photos were taken for documentation of the sample sites and to give one a visual of slope steepness and post-fire revegetation. 
Appendix D. Hillslope 1: Backslope Assessment Transects 4-6

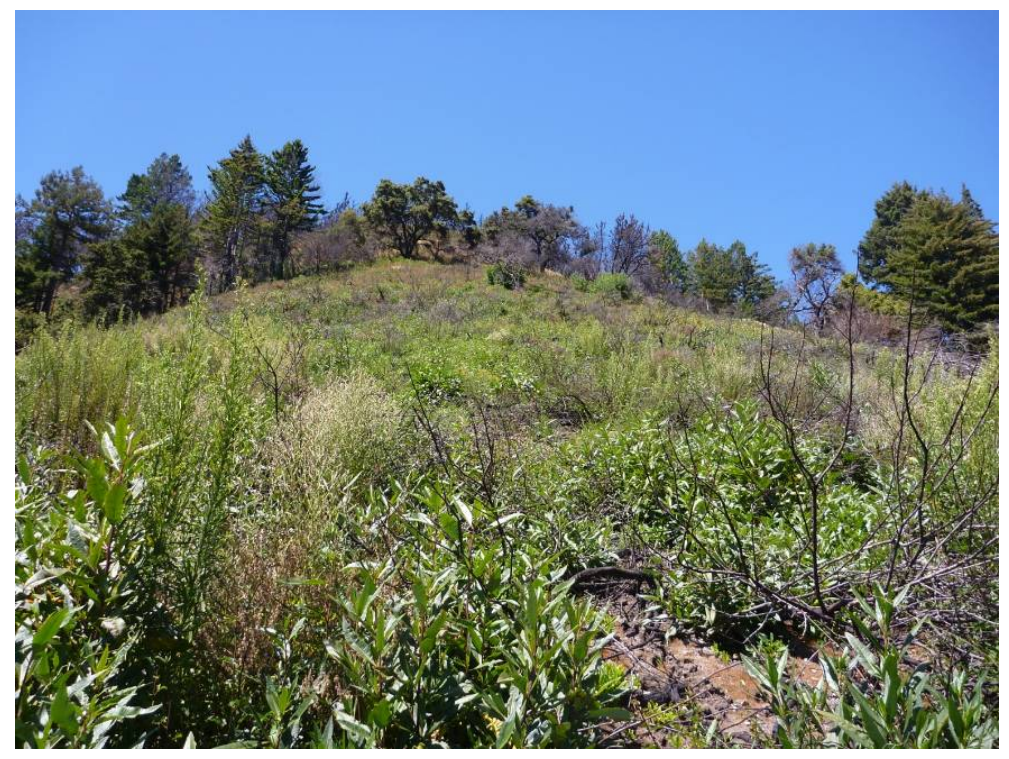

Figure 21. a) Taken from the bottom of the assessment site near transect 6 looking up toward transects 4 and 5 . This photo also displays the amount of vegetation that has grown back one year post-fire. 
Appendix E. Hillslope 2: Transects 8-9
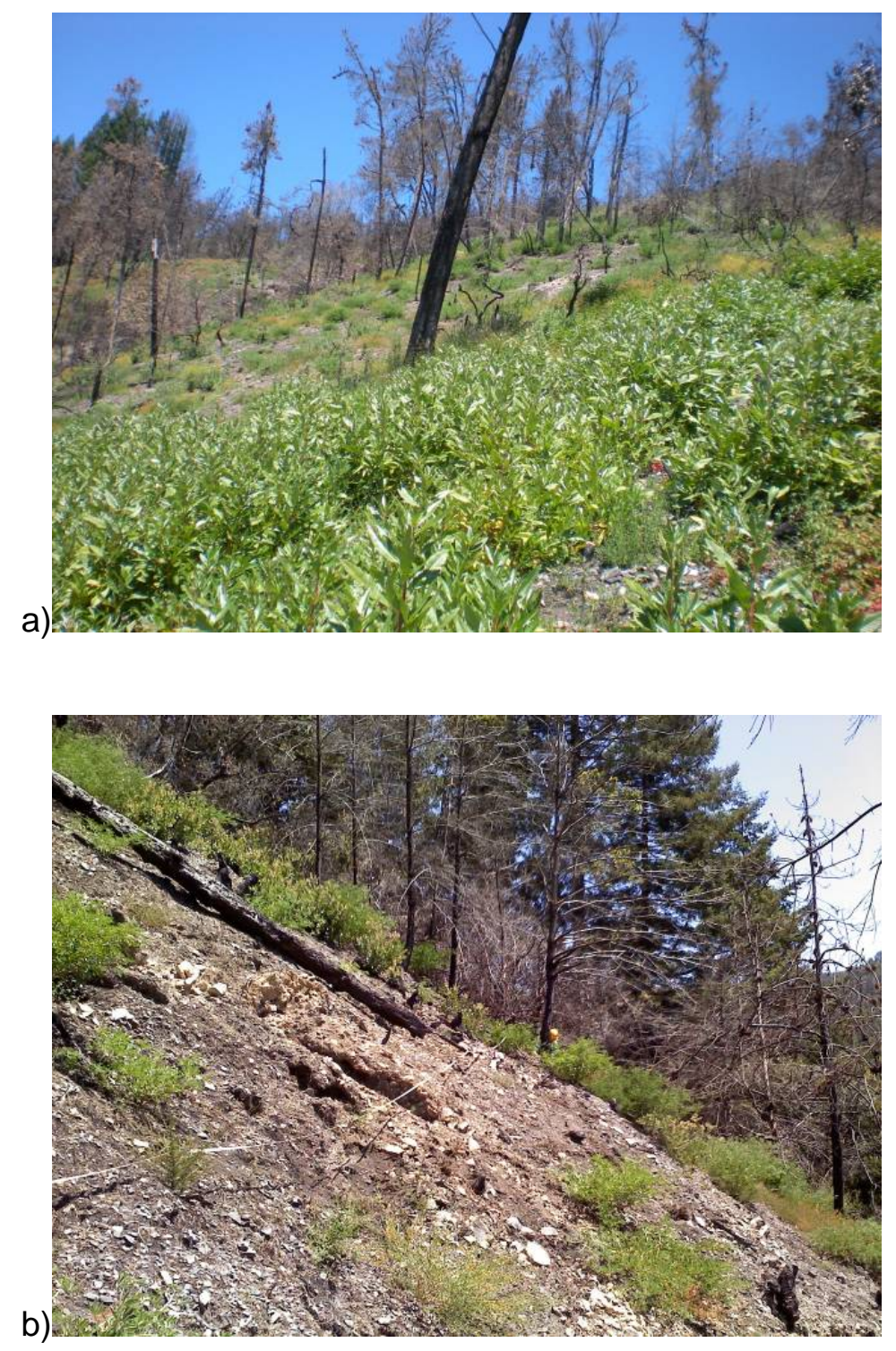

Figure 22. Hillslope 2, a) Photo of Shoulder backslope transect T8, b) Photo of transect T9 
Appendix F. Hillslope 2: Backslope Pedon 3, Transect 10-11
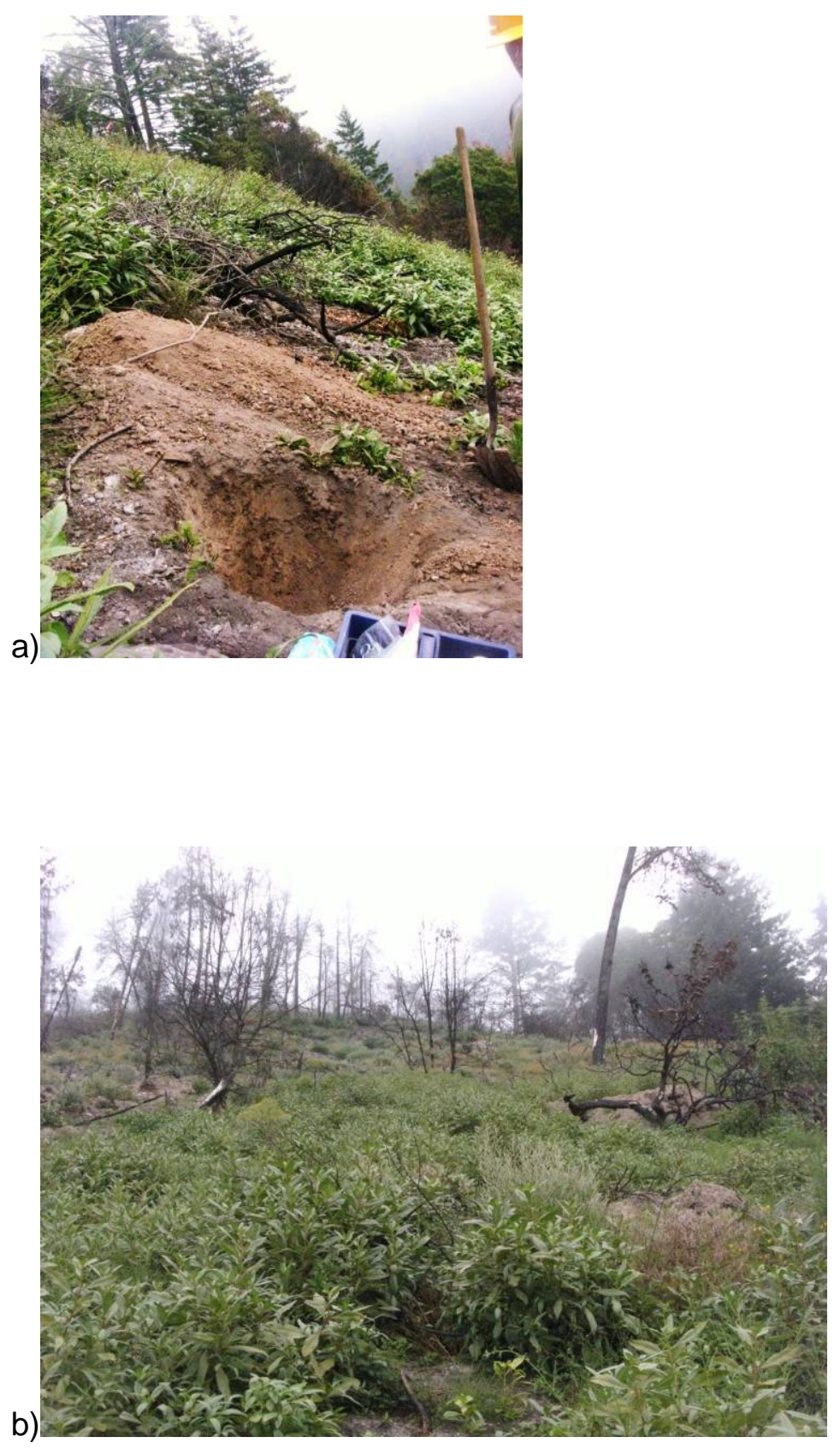

Figure 23. Hillslope 2, a) Photo of transect 10 and Pedon 3, b) Photo looking up slope from T11 
Appendix G. Statistical Analysis, Binary Logistical Regression

Binary Logistic Regression: Some Rilling versus Clay $\%, 1 \mathrm{~cm}-3 \mathrm{~cm}$ infi, ...

Link Function: Logit

Response Information

$\begin{array}{llrl}\text { Variable } & \text { Value } & \text { Count } & \\ \text { Some Rilling } & \mathrm{y} & 13 & \text { (Event) } \\ & \mathrm{n} & 17 & \\ & \text { Total } & 30 & \end{array}$

Logistic Regression Table

$\begin{array}{lrrrrrrr} & & & & & \text { Odds } & 95 \% \text { CI } \\ \text { Predictor } & \text { Coef } & \text { SE Coef } & Z & \text { P } & \text { Ratio } & \text { Lower } & \text { Upper } \\ \text { Constant } & -10.5075 & 6.42661 & -1.63 & 0.102 & & & \\ \text { Clay \% } & 0.537766 & 0.268157 & 2.01 & 0.045 & 1.71 & 1.01 & 2.90 \\ \text { 1cm-3cm infiltration } & 0.443715 & 0.210875 & 2.10 & 0.035 & 1.56 & 1.03 & 2.36 \\ \text { ksat cm/hr log } & -0.751828 & 1.67938 & -0.45 & 0.654 & 0.47 & 0.02 & 12.68 \\ \text { Slope Length (ft) } & 0.0187648 & 0.0095530 & 1.96 & 0.049 & 1.02 & 1.00 & 1.04 \\ \text { Slope \% } & -0.102895 & 0.0686036 & -1.50 & 0.134 & 0.90 & 0.79 & 1.03\end{array}$

Log-Likelihood $=-10.577$

Test that all slopes are zero: $\mathrm{G}=19.900, \mathrm{DF}=5, \mathrm{P}$-Value $=0.001$

Goodness-of-Fit Tests

$\begin{array}{lrrr}\text { Method } & \text { Chi-Square } & \text { DF } & \text { P } \\ \text { Pearson } & 19.1651 & 24 & 0.743 \\ \text { Deviance } & 21.1541 & 24 & 0.630 \\ \text { Hosmer-Lemeshow } & 9.5740 & 8 & 0.296\end{array}$

Table of Observed and Expected Frequencies:

(See Hosmer-Lemeshow Test for the Pearson Chi-Square Statistic)

\begin{tabular}{|c|c|c|c|c|c|c|c|c|c|c|c|}
\hline \multicolumn{12}{|c|}{ Group } \\
\hline Value & 1 & 2 & 3 & 4 & 5 & 6 & 7 & 8 & 9 & 10 & Total \\
\hline $\mathrm{y}$ & & & & & & & & & & & \\
\hline Obs & $\Theta$ & 0 & $\odot$ & $\odot$ & 3 & $\Theta$ & 2 & 2 & 3 & 3 & 13 \\
\hline $\operatorname{Exp}$ & $0 . \odot$ & 0.1 & 0.1 & 0.5 & 1.1 & 1.5 & 1.8 & 2.3 & 2.7 & 3.0 & \\
\hline n & & & & & & & & & & & \\
\hline Obs & 3 & 3 & 3 & 3 & 0 & 3 & 1 & 1 & $\odot$ & $\odot$ & 17 \\
\hline $\operatorname{Exp}$ & 3.0 & 2.9 & 2.9 & 2.5 & 1.9 & 1.5 & 1.2 & 0.7 & 0.3 & $\Theta . \Theta$ & \\
\hline Total & 3 & 3 & 3 & 3 & 3 & 3 & 3 & 3 & 3 & 3 & 30 \\
\hline
\end{tabular}

Measures of Association:

(Between the Response Variable and Predicted Probabilities)

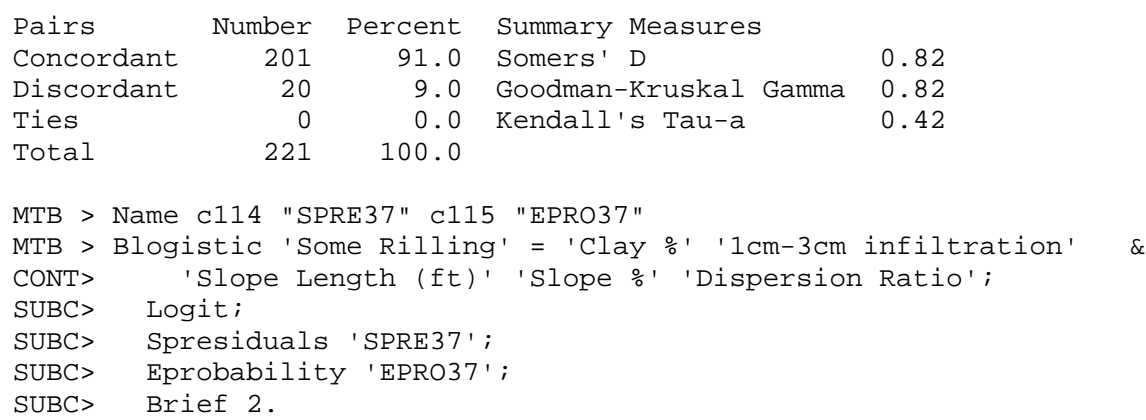


Appendix H. Burn Severity Characteristics, CalFire

Source: CalFire, 2009

Burn Severity Characteristics (adapted from Parsons, 2003):

Low:

Surface fire with no extension into the tree canopy

Slight or no modification of vegetation structure

Nearly all mature plants survive

Consumption of fine fuels and litter

Unburned islands of vegetation remain

Duff intact

No or slight soil heating

Moderate:

Long stems remaining in the chaparral

Fire extension into the tree canopy of a small number of individual trees

Moderate stand modification

Most mature plants survive, but some mortality

Needles on trees may be scorched

Consumption of fine fuels and litter

Duff layer partially consumed

Some soil heating

Some areas may be more of a mosaic of low to high severity that are lumped into the Moderate rating

High:

Chaparral mostly consumed

Most tree canopies scorched

Most small plants, litter and duff consumed

High mortality of mature plants, including trees

Some larger diameter fuels remain

Very High:

Chaparral consumption with many burned out stumps and burls

Complete consumption of the tree canopies of the majority of the trees within an area Complete consumption of small plants, litter and duff

Almost total consumption of mature plants

May be significant soil heating 
